\title{
DESCOBRINDO UM TRADUTOR BRASILEIRO: ENTREVISTA COM MARCUS TULIUS FRANCO MORAIS
}

\author{
करen \\ Marcus Tulius Franco Morais / \\ Gustavo AlthofF$^{1}$ \& CÁssia Sigle ${ }^{2}$
}

$\mathrm{M}$

arcus Tulius Franco Morais nasceu em Ituiutaba, Minas Gerais, em 1958. É professor de alemão, pesquisador na área de tradução literária, tradutor no par de línguas alemãoportuguês brasileiro ${ }^{3}$, e mestre em Estudos da Tradução pela Universidade Federal de Santa Catarina. Sua dissertação, "O fascínio da Filicida: tradução anotada e comentada de Medeia, drama de Hans Henny Jahnn” (2013), inserese no âmbito da tradução do drama, pensando a tradução do texto teatral exclusivamente na condição de texto literário. Atualmente é doutorando em Estudos da Tradução na mesma Instituição.

Sua formação é multidisciplinar. Entre 1978 e 1982 estudou Arquitetura e Urbanismo na Universidade de Brasília. Mais tarde, entre 1988 e 1994, dedicou-se à Germanística, tendo completado o curso do Departamento de Filologia da Universidade Livre de Berlim (Freie Universität Berlin). Ao longo de sua estadia na Alemanha, entre 1989 e 1990, participou de algumas oficinas de tradução: no semestre de verão de 1989 cursou a disciplina "Übungen im Übersetzen - alemão/português/alemão" e, por essa mesma época, participou da "Oficina de Tradu-

\footnotetext{
${ }^{1}$ Gustavo Althoff possui graduação em Ciências Sociais pela Universidade Federal de Santa Catarina (UFSC) (1994-1998) e Doutorado em Estudos da Tradução pela mesma instituição (2009-2012), tendo defendido a tese "Prolegômenos à Tradução de Filosofia via uma tradução comentada do An Inquiry into the Human Mind de Thomas Reid”. Atualmente é pós-doutorando do Programa de Pós-Graduação em Estudos da Tradução (PGET - UFSC). É co-editor chefe do periódico acadêmico Scientia Traductionis. Foi membro-pesquisador do NEPP - Núcleo de Estudos do Pensamento Político - de 2007 a 2009. Tem como interesses principais de pesquisa os seguintes temas: teoria política, teoria da tradução, e tradução de filosofia.

${ }^{2}$ Cássia Sigle é Bacharel em Secretariado Executivo Bilíngue pela Universidade Federal de Santa Catarina (2007), graduanda no curso de Letras Alemão (Licenciatura) e mestranda na Pós-graduação em Estudos da Tradução (PGET) na mesma universidade. Sua área de pesquisa em Estudos da Tradução envolve a interface tradução-jornalismo, o funcionalismo alemão e a tradução no ensino de línguas estrangeiras.

${ }^{3}$ Morais é um dos cinco tradutores do par de línguas alemão-português registrado no Literarisches Colloquium Berlin. Disponível em: <http://www.uebersetzercolloquium.de/index.php?id=10>. Acesso em: 15 jun. 2013.
} 
ção” do Prof. Dr. Berthold Zilly, no Instituto de Estudos Latino Americanos daquela universidade. Antes de ir para a Alemanha, também estudara francês, inglês e alemão. Seus conhecimentos da língua alemã começaram a ser coligidos em cursos do Instituto Goethe, no Brasil, e em 1982 foi estudá-la na própria Alemanha, em Friburgo (no sudoeste do país) e Munique (no sudeste). Também morou um ano em Londres, onde estudou inglês, e passou alguns meses na França (em Enghien-les-Bains, a quinze minutos de trem da Gare du Nord e de Paris-la-Défense), onde estudou francês. O espanhol que sabe aprendeu falando com los hermanos da Bolívia, do Peru, e principalmente da Venezuela, onde vive uma de suas irmãs. Voltou da Europa para o Brasil em 1996, sete anos após a queda do muro de Berlim, fenômeno político e social que testemunhou de perto. O mergulho numa próxima língua estrangeira envolve passar ser seis meses em São Petersburgo, entre o outono e o inverno, com o russo de Dostoiévski, Maiakóvski, e de outros autores.

No ano 2000, Morais fundou sua própria editora, em São João del Rei, Minas Gerais: a Ugrino. Foi através da editora que colocou em prática seu "projeto editorial de tradução”, que objetiva apresentar aos leitores brasileiros obras literárias de autores alemães, principalmente da primeira metade do século XX - autores como Joseph Roth (1894-1939), Frank Wedekind (1864-1918) e Hans Henny Jahnn (1894-1959), membros de uma geração de prosadores e dramaturgos inéditos no Brasil que, em 1933, ano em que Hitler tomou o poder, tiveram suas obras retiradas de circulação e queimadas. Pela Ugrino publicou de Roth a novela Die Legende vom heiligen Trinker (A Lenda do Santo Beberrão) (2000), e duas obras de Jahnn: uma novela, Die Nacht aus Blei (A Noite de Chumbo) (2004), e, mais recentemente, a coletânea de contos 13 nicht geheure Geschichten (Treze histórias singulares) (2011). Morais trabalha em especial com as obras de Jahnn, de quem traduziu por último a obra dramática expressionista Medeia. ${ }^{4}$

A presente entrevista surgiu de conversas informais entre entrevistado e entrevistadores. Nesta extensão mais ordenada e elaborada de tais conversas, objetivamos, por um lado, destrinçar a visão particular de Morais sobre a tradução literária, e, por outro, explorar os objetos e intentos de seu "projeto editorial de tradução". Com esse fim, trazemos à tela diversos aspectos de sua atividade de tradutor e de sua reflexão sobre essa atividade: sua inserção no cenário da tradução; as características e histórias das obras que traduz; seu encontro com a obra de Jahnn; sua relação com idéias, princípios e teorizações sobre a tradução; o desafio de lidar com a intertextualidade; a interface tradução-teatro; a fundação de sua própria editora, a Ugrino; como lidou com o desafio de traduzir os textos polifônicos de Jahnn; seu encontro com a poesia de Gertrud Kolmar (1894-1943), poetisa expressionista judaica que viveu seus últimos dias em um campo de concentração na década de 1940; assim como quais influências teve e tem na construção de sua poética de escritor e tradutor.

Em seguida à entrevista, neste documento, um dos contos de Jahnn traduzidos por Morais, "Mov", apresentado em formato bilíngue - uma amostra da intersecção artística entre Morais e Jahnn a revelar a reconstrução cuidadosa do texto alemão em português, tratada na entrevista por Morais quando comenta sobre suas escolhas de tradução para esse texto. Por fim, no documento que segue a este, uma breve tradução comentada do poema Verwandlungen, de Gertrud Kolmar.

Boa leitura!

\footnotetext{
${ }^{4}$ A tradução de Medeia está disponível aqui:

$<$ http://www.pget.ufsc.br/curso/dissertacoes/Marcus_Tulius_Franco_Morais_-_Dissertacao.pdf >
} 
Scientia Traductionis: Marcus, o que te impeliu a te tornares um tradutor? Houve algum momento-chave em que traduzir se tornou uma atividade importante em tua vida?

MARCus Tulius Franco Morais: De meados da década de 1980 a meados da década de 1990 morei e estudei em Berlim. Meu encontro com a literatura de expressão alemã gerou em mim uma necessidade de compartilhar com os amigos no Brasil os romances, as novelas e a poesia alemã, que eu, assistindo às aulas no Departamento de Filologia da Freie Universität Berlin, fui descobrindo e lendo. Assim, comecei a traduzir e a enviar aos amigos fragmentos de textos, contos, poemas, cartas. Afora isso, começaram a aparecer traduções de manuais de instruções, certidões de nascimento, de casamento, históricos escolares e acadêmicos, e interpretei em registros civis, para dar alguns exemplos dos exercícios praticados que vieram a contribuir com a instrumentação necessária para minha tarefa como tradutor.

ST: De que modo a experiência de tradução de textos de gêneros tão diversos contribuiu para tua formação como tradutor? Ademais, de que maneira essa experiência te beneficiou em teu trabalho paralelo e posterior de tradução de textos literários?

MT: Para além das traduções mencionadas, no início da década de 1990, traduzi pesquisas de estudantes e jovens profissionais estrangeiros e alemães, residentes na Alemanha, realizadas na América Latina, África e Ásia, nas áreas social, política e econômica, pesquisas essas financiadas pela Carl Duisberg Gesellschaft e. V., com sede em Berlim. Na época, a instituição enviava anualmente cento e trinta pesquisadores para os quatro cantos do mundo. Cheguei a traduzir para o português algumas dessas pesquisas realizadas no Brasil, escritas em alemão. Isso também me serviu como experiência para o ofício de tradutor. Lembro-me de uma dessas pesquisas desenvolvidas nos confins da África que tratava de planejamento urbano, reurbanização de favelas, reestruturação arquitetônica e social. Para traduzir esse trabalho valeram-me os estudos na área de Arquitetura e Urbanismo que realizei na Universidade de Brasília de 1978 a 1982. Naquela época deu para perceber que traduzir é tomar as coisas de seu pretérito e atualizá-las à medida que vão carecendo de uma nova existência num novo tempo.

ST: Quais foram os maiores desafios de tua trajetória como tradutor até agora? $E$ o que crês serem os aspectos mais gratificantes da atividade da tradução?

MT: O primeiro grande desafio foi a fundação da Editora Ugrino; depois, negociar com a Editora Kiepenheuer und Witsch, de Köln, os direitos autorais de $A$ lenda do santo beberrão, de Joseph Roth, e com a Editora Hoffmann und Campe, de Hamburg, os direitos de A noite de chumbo e Treze histórias singulares, ambos títulos de Hans Henny Jahnn. Cabe lembrar que a Hoffmann und Campe foi fundada em 1781, e é a Editora de Heinrich Heine e Günter Grass. Para minha grande surpresa e alegria, fechei, em 2001, os dois contratos desses meus dois títulos prediletos, e que hoje, alguns anos depois, encontram-se traduzidos 
e editados pela Ugrino. Desafiadores também são o trabalho, a tradução, a labuta cotidiana com as palavras, o embate constante e irremediável fundamental feito ar aos pulmões, à vida.

Outros aspectos gratificantes são as trajetórias e os caminhos que se abrem à medida que vamos desbravando os horizontes dos autores. A pesquisa em torno do nome de Hans Henny Jahnn me levou à Dinamarca, no início da década de 1990, interessado em conhecer sua filha, Signe, que datilografou grande parte dos manuscritos do pai. Com ela tomei uns goles de Schnaps de cereja de sua boa produção caseira. Contou-me histórias sobre o pai e alegrouse com meu projeto de traduzi-lo ao português. Nessa casa de campo perto da fronteira com a Suécia, Ingve Jan Trede, filho adotivo de Jahnn, preparara um pequeno concerto para mim. Em seu instrumento preferido - o cravo -, tocou peças de Jean Phillipe Rameau, Sweelinck, Bach. Enorme alegria! Jahnn [sua obra] levou-me a conhecer o escultor Paul Pfarr, em Berlim, e ver sua instalação "A noite de chumbo", uma homenagem a Jahnn, em seu modesto ateliê de $800 m^{2}$ - um piso de uma antiga fábrica.

Gratificante também é experimentar a fantasia transgressora das linguagens desses autores, aperceber-se de outras formas de percepção de questões literárias, artísticas e políticas. Minha ocupação com esses autores, com suas obras e minhas traduções de seus textos compõem o meu ofício, o meu norte.

\section{ST: Como escolhes as obras literárias que traduzes? Quais os critérios dessas escolhas?}

MT: Na tradução que me atrai assumir como tarefa, refletir sobre os personagens é refletir sobre a vida que levamos. A escolha da novela Die Legende vom heiligen Trinker (A lenda do santo beberrão), de Joseph Roth, por exemplo minha primeira tradução a ter sido publicada pela Ugrino, pequeno selo editorial que fundei em 2000 -, foi movida por meu fascínio pelo modo como o escritor transforma a realidade: ele faz um milagre. Mesmo vivendo em condições muito difíceis (familiares e amigos encarcerados e assassinados nos campos de concentração), recusa-se a oferecer "monstros" ao público. Apesar de tudo o que está vivendo, Joseph Roth tem fé, esperança e amor ao próximo. A lenda, seu testamento, narra a história do pobre Andreas que continua acreditando em milagres e prefere a ilusão ao desespero. A fragmentação da vida de Roth - em especial a dos últimos anos - transparece nessa imagem de um homem já avesso a toda e qualquer sociedade.

A empatia e a familiaridade que sinto em relação a alguns escritores e o motivo que me leva a escolher uma obra e não outra é, principalmente, a errância, homens errantes - homo viator -, desterrados, autores sem raízes, sem lugar - bodenlos -, que viveram atravessando fronteiras. Isso está estampado em seus textos e está estampado também em minhas traduções.

De modo geral, eu escolho as obras que quero traduzir. Os títulos, Die Nacht aus Blei (A noite de chumbo) e 13 nicht geheure Geschichten (Treze histórias singulares), ambos do prosador e dramaturgo alemão Hans Henny Jahnn, foram obras que eu escolhi. Suas traduções foram financiadas pelo governo alemão e fazem parte do programa criado pelo Instituto Goethe com apoio do Ministério das Relações Exteriores daquele país com a finalidade de difundir e promover a literatura e a cultura alemãs mundo afora. 
Interessante também observar as casualidades ao longo de nossas vidas, os encontros fortuitos, dando novos rumos aos nossos projetos. Em 2008, em São Paulo, conversando com o editor da Globo, Ronald Polito, que, ao lado do também editor Joaci Furtado, preparava as publicações da Globo, aquele me apresentou a lista dos seus títulos preferidos; entre eles, dois de Frank Wedekind. Eu conhecia ambos: Frühlingserwachen (O despertar da primavera) e Mine-Haha oder Über die körperliche Erziehung der jungen Mädchen (MineHaha ou Sobre a educação corporal das meninas). Da novela Mine-Haha eu fiz uma primeira versão em português, muito rapidamente, sob o fascínio da leitura extasiante que é esse texto de Wedekind. A Globo tomou conhecimento de minha tradução e, trocando informações com Marcelo Vessoni, editor da Luzes no Asfalto, um pequeno selo editorial de São Paulo, despertou-lhe o interesse; saiu por essa editora a publicação, em 2010, da novela Mine-Haha, cuja edição também conta com a tragédia infantil de Wedekind: $O$ despertar da primavera, tradução de Claudia Abeling.

ST: Retomando a maneira de escrita desses autores "sem raízes" a que aludiste com o adjetivo alemão bodenlos, te fascina o modo como transformam a realidade, operando "um milagre". De que modo detectas, percebes e classificas tal marca peculiar da operação de "um milagre” na escrita desses autores? Pois essa marca revela supostamente não somente seus estilos, mas também seus sentimentos em relação ao bodenlos, não?

MT: Os autores que traduzo viveram expatriados, no exílio, e não perderam a oportunidade de falar sobre o sofrimento e as necessidades que existem dentro e fora de nós. Falaram daquilo que os inquietou, do que sofreram na própria pele. Na linguagem poética, esses escritores desterrados encontraram uma espécie de referência, sua pátria temporária, tendo podido aí refletir sobre seus passados, suas origens e sobre suas próprias biografias.

Com o fim da República de Weimar, a violência avassaladora do Nacional-Socialismo alemão descartou o que lhe pareceu inoportuno. Entre essa leva de destituídos de seus direitos contam-se centenas de escritoras e escritores. Como Roth, emigraram, depois da tomada do poder por Hitler, os indesejados naquela terra alemã, fadados a desaparecerem no desterro. Na literatura escolhida para minhas traduções, seus autores procuraram retratar lugares na Alemanha, Áustria e França marcados por contrastes sociais e cheirando a melancolia e a dor, como podemos ler na seguinte passagem. Muitos protagonistas de suas prosas surgem assim: as pessoas vestidas em seus trajes domingueiros tinham uma expressão de sombras voláteis, festivas, surgidas em vão. Era como se o domingo tivesse sido cancelado e houvesse, em seu lugar, um buraco sombrio e chuvoso decorrente da segunda-feira, no qual aqueles que andavam perdidos, fantasmagóricos e corpóreos ao mesmo tempo, pareciam serem feitos de cera, em minha tradução das palavras do personagem Nikolai Brandies, no romance Rechts und Links (Direita e Esquerda), de Joseph Roth, publicado pela Editora Gustav Kiepenheuer em 1929, p. 32. Um pouco mais adiante, (p. 34), Roth fala de si mesmo quando faz Brandies dizer: As pessoas ainda têm ideais e princípios, casas e escolas, identidades e passaportes. Elas são patriotas ou expatriadas, belicosas ou pacifistas, nacionalistas ou internacionalistas. Eu não 
sou nenhuma dessas coisas. No passado, tive países, pátria, mas tudo foi por água abaixo. Acreditei nas coisas, elas evaporaram.

\section{ST: Um dos outros escritores alemães que traduzes ao português do Brasil é Hans Henny Jahnn. Como foi teu encontro com esse escritor-dramaturgo e sua obra?}

MT: De fato, até aqui sou seu tradutor e editor no Brasil, detentor dos direitos autorais dos títulos que traduzi: Die Nacht aus Blei (A noite de chumbo) e 13 nicht geheure Geschichten (Treze histórias singulares). Quanto ao meu encontro com Hans Henny Jahnn e sua obra, isso se deu lá pelos idos do começo dos anos 1990, em Berlim. Albrecht Heyn, diretor de teatro, com quem vivi em 1987 na Leberstraße (rua onde nasceu e cresceu Marlene Dietrich), em Berlin-Schöneberg, deu-me de presente Die Nacht aus Blei. Certa noite, peguei o exemplar, li a primeira página e notei uma linguagem expressionista distinta da que eu, até então, conhecia. Essa soou-me singular; e instigou-me a forma de exposição do espaço físico urbano, pano de fundo da novela de Jahnn. Fascinou-me sua linguagem penumbrosa, tocante e comovente. O Expressionismo alemão nos é conhecido através do cinema, das artes plásticas e da música. Da literatura, conhecemos muito pouco, e é também por isso que traduzi Die Nacht aus Blei, um belo exemplar desse movimento literário que traduz com precisão aqueles tempos sombrios da primeira metade do século XX europeu. O texto trata da trajetória de Matthieu numa cidade desconhecida. Ele atravessa, sozinho, uma longa noite, na qual todos os personagens são radicalmente desenraizados: não tem passado, não têm história, não têm futuro. A trajetória penosa e estafante de Matthieu liberta-nos, e essa foi uma das razões que me levou a traduzir esse homem setentrional singular que foi Hans Henny Jahnn.

Quanto à narrativa do prosador e dramaturgo, esta assemelha-se a composições musicais. Sua linguagem é audaciosa e variegada. Às frases breves sucedem-se arrebatamentos em fluxos de pulsações rítmicas e longos monólogos introspectivos. Tal linguagem, combinada com seus Leitmotive, confere aos seus textos essa qualidade polifônica e faz deles verdadeiras fugas verbais. Em seu romance Fluss ohne Ufer (Rio sem margens, ainda sem tradução integral ao português), o narrador vê o mundo através dos olhos e da sensibilidade de um compositor.

Em sua obra, há revolta contra a organização humana, que para ele é uma máquina que produz manipulação, vício, sofrimento e injustiça, sobretudo contra a sorte das criaturas. Preocupado em ser o mais verdadeiro possível, tem ciência do problema da escritura. Para ele, a existência pode ser fixada na medida em que se consegue ressuscitar imagens na memória e encerrá-las no casulo da palavra. Sua prosa é um hino às paisagens, aos animais, aos elementos naturais, que são insubstituíveis.

Em língua portuguesa não conhecemos a obra de Jahnn. Ao lado de outros autores alemães de vasta cultura erudita, ele é pouco lido além do Reno. Alguns escritores e poetas do exílio encontraram ressonância em outras culturas. No caso de Jahnn, começa a ser traduzido para algumas línguas européias, principalmente para as línguas escandinavas, talvez porque fugindo das filas de recrutamento, Jahnn viveu décadas de exílio entre as florestas, os fiordes e os glaciares de Bjørnstjerne Bjørnson e Henrik Ibsen. 
ST: Afirmas que a $A$ noite de chumbo "traduz com precisão" os tempos sombrios da primeira metade do século $\mathrm{XX}$ europeu. $\mathrm{O}$ que queres dizer com essa metáfora, de uma obra "traduzir", e "com precisão", um tempo, uma época, uma era? Em grande medida o que te perguntamos é: quão capaz e poderosa e apropriada pode ser a literatura para revelar e desnudar e narrar a História?

MT: Muitos personagens de Jahnn, Wedekind e, principalmente, de Roth, são símbolos da cultura europeia descritos com uma vivacidade que faz com que transcendam o pequeno mundo desaparecido de onde vieram. Os acontecimentos surgem com a força que a experiência possui. Servindo-se à criação verbal, esses autores dão um encadeamento à linguagem, evocando em nós, seus leitores distantes, vidas remotas que não conhecemos e às quais não teríamos acesso. $\mathrm{O}$ ato de escrever desses autores se manifesta como paixão no sentido original da palavra. Esses prosadores e dramaturgos conferem a posição precisa de cada palavra; seu acerto, a forma, constitui o texto. O conjunto das palavras é capaz de criar a forma, que não pode ser substituída por uma inflação de palavras. Essas escrituras não são apenas documentos, são também instantes poéticos. O que há de singular nesses autores é a capacidade de cercar mesmo os objetos aparentemente triviais com a aura de seu olhar. Quando alcançam o leitor - nós -, seu valor se multiplica e nos traz a consciência mergulhada no esquecimento.

ST: Em 1996 retornaste da Alemanha ao Brasil. O que motivou esse retorno? Teve isso algo a ver com esse teu projeto tradutório desses autores alemães desterrados de quem nos falas?

MT: Nessa época, comecei a sentir necessidade de ouvir falantes de língua portuguesa, ouvir gente conversando, dialogando, na rua; outros tons e registros, dos quais forçosamente me via distante, como o do discurso público e o da dramaturgia. Âquela altura, meu acervo linguístico havia perdido, de certa forma, parte de sua substância plástica, maleável, rítmica, musical, viva, que é o material para nossas traduções. Aqui não posso deixar de pensar no Segundo Princípio da Carta aberta sobre tradução, de Martinho Lutero (2006 [1530]), em que ele fala da importância da observação dos modos de o homem comum usar a língua. É isso mesmo! Precisei rever o mundo em língua portuguesa.

ST: Trazes à baila algo muito instigante: o papel da "língua viva" na tarefa tradutória. Na carta de Lutero que mencionas, ele justifica seu uso de allein (somente) em sua tradução da Bíblia onde não se tem esse advérbio no original grego; diz: "Se tanto a língua latina como a grega não procedem desta forma em todos estes idiomatismos, ${ }^{5}$ a alemã procede assim, e é de sua propriedade usar a palavra allein a fim de que a palavra

\footnotetext{
${ }^{5}$ Lutero acabara de mencionar certas frases que só seriam 'idiomáticas’ em alemão, isto é, que só estariam acordes aos usos diários e correntes da população de fala alemã de seu tempo, caso tivessem nelas o advérbio allein; Estes são seus exemplos: "Der Baur bringt allein Korn, und kein Geld [O camponês traz somente grãos e nenhum dinheiro]. Nein, ich hab wahrlich jetzt nicht Geld, sondern allein Korn [Não, realmente agora não tenho dinheiro, mas apenas grãos]. Ich habe allein gegessen und noch nicht getrunken [Eu somente comi e ainda não bebi]. Hast du allein geschrieben und nicht durchgelesen? [Apenas escreveste e não leste?]” (103).
} 
nicht ou kein resulte mais plena e clara. Pois, embora eu também possa dizer: 'Der Baur bringt Korn und kein Geld', assim dita, a expressão kein Geld não soa tão plena e clara como quando eu digo: 'Der Baur bringt allein Korn und kein Geld' [O camponês traz somente grãos e nenhum dinheiro]: aqui a palavra allein ajuda a palavra kein a produzir uma fala plena, alemã, clara". $E$ continua: "Pois não se tem que perguntar às letras na língua latina como se deve falar alemão, como fazem os asnos, ${ }^{6}$ mas sim há que se perguntar à mãe em casa, às crianças na rua, ao homem comum no mercado, e olhá-los na boca para ver como falam e depois traduzir; aí então eles vão entender e perceber que se está falando em alemão com eles” (2006 [1530], 103-105). Paralelo a isso, em tua resposta anterior, as referidas plasticidade, maleabilidade, rítmica, musicalidade e vivacidade da língua parecem corresponder às cores de uma paleta, isto é, a um amplo universo de possíveis tons que se pode produzir para compor uma tela. $E$ isso faz lembrar outra passagem de Lutero, do mesmo texto: "Pois quem quiser traduzir deve possuir um grande acervo de palavras, a fim de que possa ter à mão a melhor quando uma delas não soar bem em nenhum lugar" (109). Extrapolando o que ele e tu afirmais sobre o uso e o conhecimento da língua na qual se traduz, seria o caso de dizer, pois, que quanto mais tons se puder produzir, quanto maior o acervo de palavras à disposição, mais factível é a condução de diferentes projetos de tradução e mais rico é o diálogo entre tradições literárias via tradução? E retomemos o objetivo declarado de tua volta ao Brasil: cumpriu-se?

MT: Traduzindo, pode-se perceber que a cada dia alguma coisa se cumpre, alguma coisa ressurge em outro lugar, com uma nova roupagem, em outra língua. Já tem algum tempo que retornei ao Brasil, são inúmeros os anos que me possibilitam um laboratório linguístico cotidiano assonante e dissonante. Do outro lado da moeda, de minha lida com a língua alemã, meu par tradutório junto à língua portuguesa, o desafio é algo similar. Para enfrentá-lo tenho contatos na Alemanha, conhecidos, amigos, que são também meus interlocutores, com quem conto como suporte linguístico para os problemas (inúmeros e constantes) de ordem tradutória, para eventuais esclarecimentos, entendimentos e diálogos, que considero fundamental para essa troca de uma coisa por outra (palavras?), um toma lá dá cá, uma transferência cultural mútua. Sigo ainda determinado princípio fundamental ao tradutor e assonante à segunda passagem extraída de Lutero: assenhorear-se da maior gama possível de palavras, a fim de nortear decisões e fazer das estranhezas da cultura de partida algo reconhecível na cultura de chegada.

ST: Tua menção a essa relação da "troca de uma coisa por outra (palavras?)” nos evoca a questão histórica da dicotomia entre 'tradução literal' vs. 'tradução do sentido', 'ad verbum' vs. 'ad sensum', ou, colocada de outro modo por Friedrich Schleiermacher "ou o tradutor deixa o autor o mais possível em paz e leva o leitor ao seu encontro, ou deixa o leitor o mais possível em paz e leva o autor ao seu encontro (2011 [1813], 22)". Nessa esteira conceitual, o tradutólogo (e tradutor) francês Antoine Berman (2007 [1985]) oferece uma versão muito particular do que seria uma 'tradução li-

\footnotetext{
${ }^{6}$ Os “asnos” a que Lutero se refere são os papistas, críticos de sua tradução da Bíblia.
} 
teral'. Para ele, tal tradução estaria baseada na "letra” e não na "palavra"; tradução da "letra” entendida como um traduzir que presta atenção aos jogos de significantes, o espaço no qual o literário brinca com o significado, com o sentido e o conteúdo do texto. Enquanto tradutor das complexas e polifônicas obras de Hans Henny Jahnn, coadunam-se o conceito de "letra" bermaniano e tua percepção e experiência de tradutor de literatura, de tradutor de Jahnn?

MT: Pensando com Berman, importante para a nossa tradução é se abrir ao estrangeiro, às novas possibilidades, e se redefinir assenhoreando-se de um novo conhecimento, abrindo-se para uma nova experiência. Para Berman e para nós, no que tange à poesia, ao texto estratigráfico polifônico de Jahnn, entendemo-lo como trabalho de artesão na peleja com as palavras e a forma, sem sacrificar o sentido do texto dado. Não se trata unicamente da transmissão de conteúdos e mediação entre culturas, mas de uma forma de se relacionar com o Desconhecido, o Estrangeiro. Em sua obra A prova do estrangeiro: cultura e tradição na Alemanha romântica (2002), Berman escreve que "a tradução se situa justamente nessa região obscura e perigosa, na qual a estranheza desmedida da obra estrangeira e de sua língua corre o risco de se abater com toda a sua força sobre o texto do tradutor e sua língua, arruinando assim a sua empresa e deixando ao leitor apenas a Fremdheit [estranheza] inautêntica” (Berman, 2002: 278). Para ele, a boa tradução é a "tradução da letra”, ou seja, abrir no nível da escrita uma certa relação com o Outro, fecundar o Próprio pela mediação do Estrangeiro.

ST: Em tua dissertação de mestrado, intitulada “O fascínio da Filicida: tradução anotada e comentada de Medeia, drama de Hans Henny Jahnn” (2013), de um ponto de vista teórico-conceitual, te aproximas da tradução de drama a partir das ideias do pensadores do Funcionalismo Alemão (ou Teoria do Escopo [Skopostheorie]), em particular de Hans Vermeer, Katherina Reiß e Christiane Nord, assim como da reflexão sobre tradução literária do tradutólogo (e tradutor) francês Antoine Berman. De que maneira a teorização ou a reflexão desses pensadores te ajudaram a construir uma percepção própria da tradução de drama? Mais - provocativamente mesmo: há como pensar a tradução de drama, com a sua característica própria da 'performatividade', 7 sem levar em conta a ideia de “escopo"? ${ }^{8}$

MT: É no âmbito das reflexões da Teoria do Escopo, do "Funcionalismo Alemão, (ao que os nomes de Vermeer, Rei $\beta$ e Nord estão necessariamente vinculados), nosso quadro teórico principal para a prática da tradução, que pensamos critérios e parâmetros para iluminar nossas estratégias e escolhas. Além desses teóricos, também levamos em conta as reflexões de Berman e os estudos acerca da tradução teatral fundados na abordagem cultural de Susan Bassnett \& André Lefevere e de Patrice Pavis.

\footnotetext{
${ }^{7}$ Referimo-nos aqui à noção de que o texto dramático deva funcionar para o palco. A tradução que leva em conta essa valia busca integrar o texto ao contexto de encenação.

${ }^{8}$ A palavra skopos vem do grego e significa 'objetivo', 'propósito'. No contexto da Skopostheorie diz respeito ao propósito da tradução, à função que a tradução exercerá na cultura de chegada.
} 
Os princípios da Teoria do Escopo, de Hans Vermeer, e da tradução funcionalista, de Christiane Nord (se quisermos ser rigorosos na associação de idéias a nomes), já se encontram no trabalho de Katharina Rei $\beta$, quando ela se refere ao "objetivo" (Zweck) da tradução como o critério principal de sua realização, em vez da "função" do texto de partida. Paralelo a isso e concorde à teoria de Berman, entendemos que a obra literária deve ser pensada para além da comunicação; ela é a manifestação de um mundo - no caso da Medeia de Jahnn, as palavras são majestosas e ocupam um reino particular. Ademais, para nós o original não é somente um texto de partida, como postula o Funcionalismo Alemão, mas sim uma produção artística única e singular que garante ao leitor, através de sua sensibilidade, a abertura e a descoberta. De um ponto de vista da prática, a tradução teatral oferece ao tradutor duas macro-possibilidades bastante claras, ambas no contexto da cultura de chegada: integrar a tradução do texto dramático ao contexto da encenação, privilegiando seu caráter performativo, por um lado, ou, como é o nosso caso, traduzir o texto dramático exclusivamente na condição de texto literário. Acredito que minha contribuição, mais do que servir à redação de uma dissertação, poderá ter alguma valia na continuidade de uma visada ética, conceito de Berman, ou seja, abrir no nível da escrita a experiência de outro mundo.

ST: Por que Jahnn, em 1925, com sua versão da tragédia Medeia, retoma o tempo das guerras persas entre 490 e 478 a.C.? Qual a importância desse recorte histórico para o povo alemão da década de 1930? O que a personagem Medeia tinha a dizer aos leitores alemães? $\mathrm{E}$ por que decidiste traduzi-la ao público de língua portuguesa?

MT: Jahnn ocupou-se dos dramas homônimos de Eurípides e Franz Grillparzer, e remontou às fontes gregas, veiculando elementos mitológicos arcaicos do Antigo Egito e da Babilônia, chamando a atenção, por meio de sua recriação da obra, para o fato de que na Europa de seu tempo ressurgiu uma valorização racial. Sua Medeia, a personagem, não é proveniente das longínquas regiões do Mar Negro, tal como donde a buscou Eurípides; ela é africana, negra. Com isso Jahnn quis expressar seu descontentamento, sua revolta e sua recusa frente a essa corrente de valorização racial de seu tempo. O dramaturgo nos coloca a seguinte questão: "Por que os negros devem ser bárbaros para nós, como os colquidianos eram para os gregos?” A Medeia de Jahnn é uma mulher que consegue discutir aquilo que a Medeia de Eurípides não pôde. Em Jahnn, a tríplice condição de mulher, de mãe e de pessoa negra de Medeia se eleva à posição de luta, não pelo orgulho ultrajado, mas pela voz que pode finalmente ser ouvida pelo traidor Jasão. Medeia segue falando como no original de Eurípides, mas recebe de Jahnn uma inteligência distinta que a coloca em espaço equilibrado de debate com Jasão. Isso, para além da recepção feminista, é o que parece outorgar real cidadania à estrangeira africana na percepção do leitor contemporâneo.

Depois de traduzir dois volumes da prosa jahnniana [Die Nacht aus Blei (A noite de chumbo) e 13 nicht geheure Geschichten (Treze histórias singulares)], a escolha de traduzir Medeia diz respeito à linguagem teatral, para mim um desafio, visto que a tradução de textos dramáticos exige conhecimentos específicos que até o início de minha ocupação com o drama de Jahnn eu ignorava. Creio que sua tradução se revela muito bem-vinda e útil para o atual 
momento da classe teatral brasileira, seja para os trabalhos de realização cênica, seja para a pesquisa teórica. Mais do que um mundo crível, vivo, ainda que fictício, despertando no público o desejo de participar dos acontecimentos que sucedem nesse mundo, o teatro atual, no que diz respeito à sua recepção, talvez se ajuste mais aos questionamentos da busca do teatro contemporâneo, do espectador ativo (versus passivo), na esteira das pesquisas de Bertolt Brecht e Antonin Artaud.

ST: Em seu livro Exploring Tanslation Theories (2009), Anthony Pym agrupa as teorias da tradução a partir do conceito de 'paradigma', uma unidade conceitual definida como o conjunto de princípios correlatos que subjazem a diferentes teorias individuais. Um dos paradigmas que elenca é o da 'Incerteza', em que teorias diversas compartilhariam a visão de que os significados de textos complexos (como os grandes textos literários) jamais são inteiramente recuperados na tradução. De que maneira vês essa questão na tua experiência de tradutor de textos literários polifônicos como os de Roth, Wedekind e Jahnn?

MT: Não há uma maneira unívoca de interpretar uma grande obra em suas ressonâncias profundas e múltiplas. Com suas escrituras, esses autores são capazes de retratar a realidade em tal medida que podemos vislumbrar um quadro da época em que foram escritas. E não é unicamente a obra que nos fascina, o que também nos chama a atenção é a identidade entre a obra e a pessoa desses autores, na transparência de cada um de seus textos e de cada individualidade, suas vidas. Na condição de tradutor desses autores, visto a pele do poeta, procuro ver o mundo além da superfície das aparências e trazer as relações humanas e os acontecimentos históricos a um ponto que ora se apresenta inacessível ao olho. Nesse encargo me é fundamental apreender a linguagem desses artesãos da linguagem, que sentem a vida com uma intensidade extasiante; essa experiência vital, a vivência de cada um deles - uma realidade personalíssima e singular -, é o resultado da somatória de instantes captados com a lupa fugaz da existência: os olhos do poeta.

ST: Em texto inédito, a ser publicado no DITRA (Dicionário de tradutores literários no Brasil), ${ }^{9}$ dizes de tua tarefa que “o desafio posto pela tradução é recuperar em português a fluência que o texto tem em alemão". Também em tua dissertação de mestrado, dizes de tua atenção em conferir "a maior fluência e naturalidade ao texto [traduzido]" (2013, p.94). Lawrence Venuti, tradutólogo norte-americano, em seu The Translator's Invisibility (1995), define o conceito de "fluência" como uma estratégia de tradução cujo emprego resulta num texto transparente, de fácil leitura, destituído de peculiaridades linguísticas, que é redigido no registro padrão da língua e que dá a impressão de que é o original (1-2). Há algum paralelo entre o teu uso do termo "fluência" e o conceito de Venuti?

MT: Para Venuti, um texto (traduzido) fluente é o que apresenta características como sintaxe linear, sentido unívoco, linguagem atual. Sua crítica à estratégia

\footnotetext{
${ }^{9}$ Endereço eletrônico: <http://www.dicionariodetradutores.ufsc.br/pt/index.htm>.
} 
da fluência, que, segundo ele, predomina no sistema cultural anglo-americano, é que ela apaga a intervenção do tradutor na tradução, anulando a diferença linguística e cultural do texto estrangeiro. Nos textos que traduzo, interessa-me reconhecer e explorar essas diferenças linguísticas e culturais, e não ratificar o movimento contemporâneo de homogeneização.

No tocante à fluência em meu discurso, tem a ver com a naturalidade do texto em língua portuguesa. Jahnn expressa uma vontade manifesta pela estilização linguística, tem em alta conta estruturas rítmicas, inversões de palavras, que exploram possibilidades de combinações sintáticas do alemão até o limite do admissível, alcançando com isso um alto grau de expressão formal. Nesse sentido, nossa grande preocupação ao reconstruir suas obras é dar conta dessa linguagem, responder pelo diálogo entre ambas as formas (em alemão e em português). Portanto, ao mirarmos fluência ou naturalidade em minha tarefa, tais valias se relacionam com essas dimensões do discurso jahnniano. É Berman que nos chama a atenção devida para o problema do empobrecimento qualitativo, isto é, quando substituímos termos, expressões, modos de dizer etc do original por termos, expressões, modos de dizer, destituídos de sua riqueza sonora, icônica, entendendo por "icônico o termo que, em relação ao seu referente, 'cria imagem’, produz uma consciência de semelhança.” (Berman, 2007, p. 53).

ST: Voltando nossa mira para questões editoriais vinculadas à tradução, quais os prazos para a conclusão e entrega das traduções que realizas tanto na Ugrino quanto quando trabalhas para outras editoras? Como é o teu relacionamento com os editores? Até o presente, como se deu tua relação com os editores no recebimento ou construção dos “encargos de tradução”?

MT: No caso das traduções subsidiadas pelo Instituto Goethe, os contratos foram de três anos, o que significa que dentro desse prazo a tradução teve de ser publicada; e tão logo o Instituto receba cinco exemplares da respectiva publicação, o fomento é liberado para o editor pagar os honorários do tradutor. Em meu caso, editor e tradutor são a mesma pessoa. Para outros títulos e textos que escolhi traduzir, não estipulei datas para concluir as versões finais; as traduções foram amadurecendo na labuta com as palavras, com as pesquisas; as traduções foram amadurecendo enquanto eu ia lendo minhas versões com amigos, dando ouvido às suas opiniões, reconsiderando-as; vez e outra, as versões concluídas voltam para o anonimato das gavetas, para serem retomadas em tempo oportuno, como texto distanciado, renovado, estranho, alheios aos seus originais.

Quanto às parcerias com os editores e suas interferências, tanto Joaci Furtado quanto Ronald Polito, da Editora Globo, e Marcelo Vessoni, da Luzes no Asfalto, deixaram-me à vontade e em paz para fazer as traduções, dispondose, inclusive, a dialogarem comigo, discutindo dúvidas e decisões a serem tomadas, colaborando, dessa forma, com a exequibilidade da tarefa do tradutor.

ST: O nome de teu selo editorial, Ugrino, tem um significado específico relacionado a Hans Henny Jahnn, sim? Qual é esse significado? Ademais, com que objetivo foi fundada a editora e quais as obras por ela lançadas? Por fim, quais os princípios que guiam o "projeto editorial de tradução” da Ugrino? 
MT: Segundo Jahnn, Ugrino é um símbolo, um nome que designa uma região separada do mundo por uma fronteira imaginária, que seria possível alcançar atravessando um portal em alto-mar. Jahnn e seu companheiro Gottlieb Harms fundaram em Hamburgo, em 1921, a Editora Ugrino, que existiu até o início da década de 1930. Juntos, editaram principalmente composições musicais barrocas e pré-barrocas, como de Vincent Lübeck, Samuel Scheidt, Dietrich Buxtehude, Claudio Merulo, Jean Titzelouze, Carlo Gesualdo da Venosa, Jan Pieterszoon Sweelinck, Johann Sebastian Bach, Wolfgang Amadeus Mozart, Carl Nielsen, Yngve Jan Trede, entre outros, em edições completas e de uma qualidade gráfica excepcional. A música tem uma grande importância na obra ficcional de Jahnn. Essa influência vai de citações diretas, alusões verbais, e descrições de músicas a realizações ficcionais das mesmas. O desenvolvimento musical do protagonista do romance Fluss ohne Ufer (Rio sem margens), o compositor Gustav Anias Horn, é uma recapitulação da história da educação e do gosto musical do próprio Jahnn, incluindo seus estudos sobre a obra de Mozart e do compositor dinamarquês Carl Nielsen. A música na prosa de Jahnn torna-se, em longas passagens, um texto submerso para o discurso verbal, onde compor e escrever fluem juntos, produzindo um paradoxo crescendo e decrescendo.

A fundação da Editora Ugrino no Brasil foi a forma que encontrei para homenagear, traduzir e publicar a obra de Hans Henny Jahnn. Meu objetivo, porém, vai mais longe; explico: na Opernplatz, Praça da Ópera, em frente à Universidade Humboldt, em Berlim, foram queimados cerca de vinte mil livros na noite de primavera de 10 de maio de 1933. O Partido Nacional-Socialista pensou numa depuração (Säuberung) do país e na erradicação de todos aqueles livros que consideravam não-alemães, imorais e arte degenerada, de autores acusados de ruína moral, decadência, traição, falsificação, calúnia contra o espírito nacional. Foram devoradas pelas chamas obras de comunistas, socialistas, sindicalistas, pacifistas, judeus; de Karl Marx, Engels, Lenine e Trotzky, Henri Barbusse, Romain Rolland, Gorki, Kafka, Feuchtwanger, Max Brod, Heinrich e Thomas Mann, Bertolt Brecht, Alfred Kerr, Sigmund Freud, Walter Benjamin, Ernst Bloch, Frank Wedekind, Erich Kästner, Erich Maria Remarque, Joseph Roth, Hans Henny Jahnn, Nelly Sachs, Gertrud Kolmar, Franz Werfel, Albert Einstein, Kurt Tucholsky, Carl von Ossietzky, e centenas de outros nomes. Das prateleiras do país esses livros foram recolhidos e destruídos. O artista plástico israelita e professor da Academia de Artes de Stuttgart de 1991 a 2005, Micha Ullmann, projetou e instalou uma sala de biblioteca no subsolo dessa praça. $\mathrm{O}$ espaço foi projetado com prateleiras capazes de conter os vinte mil exemplares queimados naquele ritual monstruoso. Podemos dizer que esse silêncio de $5 \mathrm{~m} \mathrm{x}$ $5 \mathrm{~m}$ x 5m, iluminado por uma luz branca, é a ausência dos autores da nossa $U$ grino. Se penso nos poucos títulos por nós publicados, sabemos que temos um longo caminho pela frente: uma sala de biblioteca aguardando em suas prateleiras os vinte mil títulos que pretendemos traduzir.

ST: Em tua lista de autores cujas obras foram devoradas pelas chamas aparece o nome da poetisa judia Gertrud Kolmar. Na "Revista 18" (n 19, ano IV, 2007) escreves artigo sobre ela em que nos chama a atenção tua análise de seus poemas, que exibiriam trechos e intenções românticas e expressionistas, uma sintaxe singular. Além disso, destacas que “as frases vão 
se enroscando e se sobrepondo, ocultando o sentido das palavras sob uma vegetação rara” (p. 52, grifos nossos). Também fazes menção ao universo pleno de metáforas, fontes orientais, nomes míticos e etc. Enquanto tradutor do poema Verwandlungen de Kolmar - publicado em tradução comentada neste número de Scientia Traductionis -, de que maneira lidaste com essa ocultação do sentido das palavras? Como se deu o teu trabalho de reconstrução e como procedeste para te aproximares desse sentido oculto das palavras? Por fim, que expectativas pode o leitor ter ao ler tua tradução desse poema?

MT: Gertrud Kolmar faz parte de uma miríade de escritoras e poetisas que desapareceram nos campos de extermínio durante o Nacional-Socialismo na Alemanha. Em 1989, a Editora Pahl-Rugenstein publicou Verbrannt, verboten, vergessen - Kleines Lexikon deutschsprachiger Schriftstellerinnen 1933 bis 1945 (Queimadas, proibidas, esquecidas - Pequeno dicionário de escritoras de língua alemã, de 1933 a 1945), de Renate Wall. A obra apresenta cento e cinquenta bio-bibliografias de mulheres que nesse período foram vítimas da política racial do Terceiro Reich. Muitas morreram prisioneiras em campos de trabalhos forçados; outras, que conseguiram fugir, morreram esquecidas no exílio. Esse tema perdura até os dias de hoje como um capítulo da literatura de expressão alemã pouco lembrado.

Em "Procura da poesia" Carlos Drummond de Andrade nos ensina que é preciso penetrar "surdamente no reino das palavras / lá estão os poemas que esperam ser escritos”. Contemplando as palavras, percebemos que "cada uma / tem mil faces secretas sob a face neutra”, aparente, usual. Ele reitera o trabalho com a matéria-prima do poeta: a palavra. Compete-me entender o significado da palavra no verso, as imagens complexas empregadas pela poetisa e a compreensão de seu sentido conotativo. Seus versos rimados e cheios de visões em Verwandlungen conduzem a um eu lírico afeito a experimentações e recordações. A poetisa experimenta a capacidade de metamorfosear-se em animais, plantas, objetos; de dar vida às coisas mortas. Os limites e fronteiras são suprimidos, surgindo um sentimento de unidade entre a pessoa e a natureza. Isso apreendido, quis criar ritmos livres e moldar sonoridades na tradução. As perdas sonoras das rimas AA/BB, (Tuch/Fluch, scheucht/feucht), tento compensar com rimas internas: "manto", por passar a ideia de "quente", e conter a consoante "t”, gerando uma aliteração no verso, "feiTo manTo quenTe"; "veNTO afugenTANdo os cANTos”, para citar dois exemplos. Em minha tradução comentada do poema, trato desse assunto com pormenor. E sabemos que a expectativa que o leitor pode ter em relação ao nosso trabalho é o de lhe fazer coçar a cabeça e pensar no quão insignificante é o nosso ofício, quão insignificantes parecem, hoje, tantas vidas passadas, esquecidas; por outro lado, quão vital nos são essas vidas obliteradas.

ST: Ronald Polito, no posfácio de tua tradução de $A$ noite de chumbo (2004), diz de Jahnn que "permaneceu um expressionista até suas últimas obras. Ele pertenceu a uma geração de escritores barbaramente marcada por duas guerras perdidas e teve de olhar de frente para toda a teratologia advinda dessas feridas históricas que não fecham.” (p.116). Em sua obra, Jahnn se utiliza de uma superposição de impressões e expressões simbólicas 
que remetem a esse tempo histórico já distante do nosso. De que maneira te aproximaste ao expressionismo e à simbologia de Jahnn?

MT: A partir de 1950, Jahnn passa a se ocupar do projeto literário para o roteiro do filme Die Schuldigen (Os culpados). ${ }^{10}$ Em 1951, o autor o interrompe para escrever dois importantes textos de sua trajetória expressionista. O primeiro, Jeden ereilt es (Ninguém escapa), foi publicado em 1968; o segundo, a novela Die Nacht aus Blei (A noite de chumbo), foi publicado em 1956 como volume II da Mainzer Reihe (Série de Mainz) da Academia das Ciências e da Literatura pela editora Christian Wegner de Hamburgo. A novela trata de um episódio do romance Ninguém escapa, concebido como um sonho ou uma visão de Matthieu pouco antes de sua decisão de assumir a culpa de Gari, o assassino de sua noiva. Quando o escritor se recolheu à ilha de Bornholm, na Dinamarca, para concluir a Noite, afora os próprios manuscritos, trazia consigo - como sabemos de suas cartas - dois livros: A Bíblia, de Lutero, e a tradução alemã de Ulysses, de James Joyce. As marcas de ambos estão lá em seu texto: o anjo da morte Malach hamoves - e a jornada de um homem numa cidade desconhecida; ambas nos remetem à experiência histórica da Alemanha dos anos 50, da realidade da morte e da onipresença da dor, Leitmotiv recorrente na obra de Jahnn.

ST: Nesse mesmo posfácio, Polito identifica correlações intertextuais dessa obra de Jahnn com elementos estéticos presentes em outros dois autores, Franz Kafka e Edgar Allan Poe. Ao universo kafkiano, Jahnn se remeteria através de paroxismos - por exemplo, quando trata de regulações autojustificadas porque injustificáveis (como o caso da garçonete que explica ao personagem Matthieu por que o restaurante onde trabalha fica aberto mesmo sem ter o que servir: “Temos nossos regulamentos.”). Quanto a Poe, Jahnn dialogaria - ainda que indiretamente -, com elementos dos mais obscuros contos do escritor norte-americano (em particular, aponta, com "O Barril de Amontillado", a história de um encontro entre dois homens em que um convida o outro a visitar sua adega, localizada num subterrâneo muito profundo). Em que medida foste tocado por marcas intertextuais desse tipo ao traduzires Jahnn?

MT: Os textos desses autores são fortemente imagéticos nas configurações de seus espaços arquitetônicos sombrios, plásticos, com diálogos de natureza cênica, teatral, com linguagens, impressões e expressões simbólicas. Na novela de Jahnn, o protagonista Matthieu vaga por uma cidade desconhecida, quando encontra um jovem, também chamado Matthieu, ou o Outro (pois esse jovem é o próprio Matthieu com talvez 10 anos a menos). Eles cruzam juntos a cidade, são surpreendidos por uma nevasca, e seguem em direção à casa do jovem (na realidade, um subterrâneo, uma cripta profunda iluminada por uma vela), onde Matthieu percebe que o jovem está gravemente ferido no ventre, um corte entre o estômago e o umbigo, do qual se projeta parte de suas entranhas.

\footnotetext{
${ }^{10}$ Aqui <http://www.hoffmann-und-campe.de/go/ef9e934e-508b-af43-91d9e44d0195eff4> se lê que em 1950 Jahnn escreveu um rascunho do filme e que foi desse projeto que surgiu o obra "Jeden ereilt es". Acesso em: 20 jun. 2013 (nota dos entrevistadores).
} 
Na Noite, também lemos passagens sobre obediência a regulamentos absurdos, propósitos insensatos, determinações antigas, cujos juízos não mais se sabe. Paroxismos, assim, remetem diretamente ao universo kafkiano. A novela de Jahnn nos faz lembrar O Médico rural, de Kafka, conto em que um médico, depois de conseguir um cavalo com muita dificuldade, atravessa uma nevasca para atender um jovem doente com uma ferida na barriga. Diria que a obra de Kafka quis aflorar inclusive na materialidade das edições de Jahnn. A primeira edição de A noite de chumbo deveria ser publicada nos moldes de $O$ médico rural, como o fora a seu tempo, ou seja, nas mesmas dimensões da obra de Kafka, mesmas fontes e mesmos tipos gráficos.

Do universo de Poe, lembramo-nos de seus contos obscuros, a exemplo de $O$ Barril de Amontillado, destacado por Polito, cujo subterrâneo profundo aparece na cripta do Outro. Essa experiência de descida surge também em Kafka. Essa consciência de que se encontra aprisionado tem existência também no jovem de Praga. Lembro-me de conto da obra Beim Bau der chinesischen Mauer: Ungedruckte Erzählungen und Prosa aus dem Nachlass (Durante a construção da muralha da China. Contos e prosa inéditos da obra póstuma), em que os trabalhadores da construção da muralha da China se vêem presos, soterrados. Em seu trabalho sombrio e contínuo, martelam, batem, mas som nenhum reboa. As portas não têm chaves, e os buracos, que vez ou outra surgem, são imediatamente fechados.

Além dessas correlações intertextuais, há uma conexão intratextual iluminadora do conteúdo de A noite de chumbo: o pequeno conto Mov, que Jahnn escreveu lá pelos idos dos anos 1950, quando também se ocupava da novela. Esse conto narra a história de Mov Faltin, capitão de um navio que se vê no meio de uma tempestade em alto mar, quando um de seus marinheiros ferese gravemente no ventre. Pelo buraco, do seu corpo, um ferimento tarjado de castanho que ainda sangrava um pouco, saía um nó do intestino grande como uma noz, espelhando o ferimento do Outro.

Os paralelismos identificados por Polito são interessantes e alimentam a hipótese do possível diálogo entre as obras mencionadas; porém, não me causaram um imediato impacto na tradução. Agora, sempre é difícil lidar com marcas intertextuais. Em minhas traduções, quando posso acompanhar os vários aspectos da intertextualidade, das relações entre textos propriamente ditos, tanto melhor. Identificar tais marcas pode ou não ter pertinência para a tradução. No caso de Jahnn, sua biografia e bibliografia me possibilitam desenvolver ferramentas e estratégias para a tradução de fenômenos intertextuais. Suas cartas e diários apontam-me referências intertextuais e guiam-me na (re)textualização em português de seus textos. Na ilha de Bornholm, na Dinamarca, Jahnn folheava a Bíblia de Lutero e o Ulysses de Joyce. Em sua novela A noite de chumbo, o anjo da morte dirige-se ao protagonista da Noite de chumbo num patente tom bíblico: Ich verlasse dich jetzt. Du mußt alleine weitergehen. Du sollst diese Stadt, die du nicht kennst, erforschen (JAHNN, 1987, p. 247), "Eu me aparto de ti agora. Põe-te, só, a caminho. Tu vais perscrutar esta cidade por ti desconhecida”.

E na mesma Noite, uma atmosfera joyciana (ou ulissiana) se oferece ao tradutor como palco para o enredo da prosa jahnniana: Matthieu, der den Kopf gesenkt gehalten hatte, blickte auf. Er erkannte dies: daß es Nacht war - ein schwarzer Himmel ohne Sterne -; daß es Häuser gab, gepflasterte Straßen -; da $\beta$ er an einer Ecke stand, wo die Fliesen unter seinen Füßen aus zwei 
Richtungen zusammentrafen -; daß ein gelbes grelles Licht, ausgestrahlt von hochhängenden Lampen, das Bild erhellte, dies neue Bild, diese Strassenecke und einen breiten Boulevard, den er nach zwei Seiten hinabschauen konnte. Glitzernde Straßenbahnschienen lagen eingebettet im Pflaster, kamen von fern her, verloren sich im Fernen, schnurgerade, wie ihm schien, unablässig das nicht ermüdende gelbe Licht über sich, das unzählbare aufgehängte Lampen gaben. (JAHNN, 2004, p. 7), "Matthieu, que mantinha a cabeça baixa, levantou os olhos. Percebeu isso: era noite - um céu negro sem estrelas; havia casas, ruas calçadas; estava numa esquina onde os paralelepípedos vindos de duas direções se encontravam sob seus pés; um fulgor amarelo, despejado das lâmpadas pendentes no alto, clareava a imagem, esta nova imagem, esta esquina de rua e um largo bulevar que ele descortinava logo abaixo em ambos os lados. Trilhos do bonde jaziam lustrosos estribados nas pedras, vinham de longe, perdiam-se ao longe, retilíneos, como lhe pareciam, iluminados sempre por uma inesgotável luz amarela derramada das inúmeras lâmpadas suspensas”.

ST: Quais os autores que mais, e melhor, te influenciaram na construção de tua poética literária e de tua consequente poética tradutória: tua poética literária de tradução? Ao lermos a tradução de $M o v$, percebemos um toque machadiano, cremos, incontestável, em que se verifica: variedade vocabular; economia narrativa; metáforas e imagens inusitadas; uma descrição precisa dos acontecimentos; vivências psicológicas inesperadas; um desvelar sutil das impressões subjetivas dos personagens, assim como uma ambiguidade acerca do que representam. É por aí? Há algo de Machado de Assis em tua tradução, nesse concerto entre Jahnn e Morais?

MT: Há algo de todo o mundo em minhas traduções: um pouco de minhas andanças pelo mundo. Morei catorze anos no exterior, principalmente na Alemanha, Inglaterra, Suíça e França, período fundamental na minha formação como tradutor. Há algo também de minhas primeiras leituras. Ainda garoto, folheava os Märchen dos irmãos Grimm, as Fábulas de La Fontaine; adolescente, descobri, na biblioteca de meu pai, tomos bonitos que me abriram a mundos inusitados; a poesia romântica brasileira, com suas cores exóticas e descrições da natureza, das matas, corroborou o arsenal linguístico fundamental para visualizar as florestas descritas por Jahnn, ainda que opostas em suas latitudes. Para arrolar nomes de escritoras e escritores que influenciaram na construção de minha poética literária de tradução, como vocês pontuaram, eu poderia mencionar o acervo de papai que herdei: literatura brasileira e universal.

Hoje, depois de minha estada na Europa, depois de cursar Germanistik na Freie Universität Berlin, ocupo-me da prosa, lírica e dramaturgia alemãs, principalmente dos autores que traduzo. Para o fôlego do prosador Jahnn, valem-me prosadores portugueses: Camilo Castello Branco, Eça de Queirós, José Saramago. Por aqui, Machado de Assis é sempre presente com soluções das mais bem-vindas. O talento poético de Machado, com suas expressões precisas, me é de enorme valia. Lembro-me de minhas elucubrações e buscas por vocábulos e expressões para conferir sentido à tradução de Mov. A publicação desse conto na Alemanha ocorreu a partir de seleção do próprio Jahnn de uma passagem de seu romance Fluss ohne Ufer (Rio sem margens), e faz parte de sua coletânea Treze histórias singulares (13 nicht geheure Geschichten), publicada 
como livro de bolso pela Editora Rowohlt, de Hamburgo, em 1954. No Brasil, Mov foi publicado primeiramente como a décima plaquete composta para a Espectro Editorial em janeiro de 2006, em Belo Horizonte e Juiz de Fora (MG), com um desenho de capa de Marcelo AB, 1996 (grafite e tinta acrílica sobre papel Canson), com tiragem de 100 exemplares fora de comércio carimbados pelo editor Ronald Polito; posteriormente, em 2011, foi publicado pela Ugrino. Para a tradução do conto, utilizei a versão publicada em 13 nicht geheure Geschichten da Hoffmann und Campe, Hamburgo, 1995.

Esse exercício foi minha primeira tradução literária; comecei-a em 1992; por isso mesmo foram muitos anos de leitura, tradução, versões revisadas, cotejadas, discutidas, até obter uma versão possível para o primeiro leitor do texto em português: eu, o tradutor. Lembro-me da busca pela tradução do adjetivo alemão prächtig para a roupa do personagem principal do conto. Eu não me contentava com as traduções do verbete que se encontram nos inúmeros dicionários e léxicos: magnífico, vistoso, faustoso, suntuoso, de alta qualidade. Mas foi em Machado que encontrei "de truz", com o sentido "de primeira ordem”, que era o que eu buscava para adjetivar o uniforme de Mov Faltin, o capitão de um pequeno cargueiro de uma modesta companhia de navegação. No conto, lemos que seine Uniform war nicht prächtig, "seu uniforme não era de primeira ordem”, "não era de truz”, ou seja: ele usava uma jaqueta surrada, de punhos puídos - era um homem modesto. Para Machado, uma de suas personagens femininas era de truz, uma moça de truz. Apesar da inspiração inicial e, a meu ver, belíssima, o leitor não encontrará a expressão “de truz” na versão de $M o v$ publicada em Treze histórias singulares. Lá, depois de discussões acirradas em torno do verbete e de seu desuso em nosso discurso, acabei optando por "suntuoso”. Agora, porém, para a publicação neste número da Scientia, retomo a expressão "de truz", e restituo-a a sua atualidade. Com Machado, resolvi também as "pernas tortas" ( $x$-beinig) de James Botters, um marinheiro que faz parte da tripulação do cargueiro em que Mov é capitão: "suas ancas largas lhe davam um trejeito cambaio”. Entrar no mundo de Machado é como garimpar um emocionante veio de ouro literário, imprescindível em nosso ofício. Minha pesquisa tradutória implica numa constante revisita a grandes escritores da língua portuguesa.

ST: Em prefácio à tradução do conto de Jahnn de nome Der Uhrenmacher ( $O$ Relojoeiro), dizes o seguinte de sua escrita: “A linguagem do prosador e dramaturgo é audaciosa e variegada. Às frases breves sucedem-se arrebatamentos em fluxos de pulsações rítmicas, e longos monólogos introspectivos. Sua narrativa assemelha-se a composições musicais. Essa linguagem, combinada com seus Leitmotive, faz dos textos verdadeiras fugas verbais. No romance Fluss ohne Ufer (Rio sem margens), o narrador vê o mundo através dos olhos e da sensibilidade de um compositor. Preocupado em ser o mais verdadeiro possível, tem ciência do problema da escritura. Para ele, a existência pode ser fixada na medida em que se consegue ressuscitar na memória imagens e encerrá-las no casulo da palavra” (2008, p.253). E na sequência adicionas que "uma das dificuldades do tradutor é dar conta dessa linguagem polifônica utilizada pelo escritor”. Poderias nos explicar como lidaste com esse desafio na tradução de Mov, em que Jahnn também faz amplo uso de imagens e monólogos, e deixa aflorar sua sensibilidade como "compositor"? Como percebes e lidas com as nuances de sua lingua- 


\section{gem audaciosa e variegada, seu registro próprio, e com esse "casulo da pa- lavra" do autor alemão, em português?}

MT: Presente na linguagem de Jahnn, é necessário apreender o fluxo das palavras, ora ecoando num compasso rápido, ora entrecortado, criando gradações e variações na própria linguagem. Ele se serve de uma cadência expressiva ao longo de longas passagens; lemos orações compactas, paráfrases, repetições de palavras e aliterações, que busco conseguir em minha tradução, procurando, dessa forma, a dicção jahnniana. Por exemplo: "Deus me fez assim como sou, com o coração cheio desse medo de nunca ser tão adulto quanto Sophus, o ajudante de cozinha, com seus dezessete anos, e com esse contentamento, esse constante contentamento por ter sido aprovado em todos os exames e por ter-me tornado capitão.” O prosador se fia na força, na integridade, na plasticidade e na riqueza das imagens. E importante nisso é enxergar o original não somente como um texto de partida, mas sim como uma produção artística única e singular.

Faço conhecer a partir daqui como lido com isso, e com a valia da precisão referencial, na prática, através do desvelo de algumas de minhas escolhas de tradução para Mov [que pode ser lido em sua completude ao final desta entrevista]. ${ }^{11}$ Em uma passagem do conto, lemos que a tripulação do cargueiro vive em um buraco sujo de óleo e graxa da casa das máquinas. Esse lugar da nau é uma espécie de armadilha do mar para esses homens comuns. Minha escolha do substantivo "mundéu" (armadilha de caça) não foi aleatória, pois o tal buraco beira, de fato, uma armadilha do mar e do destino; "mundéu" deixa o aposento ainda mais ameaçador. E toda essa sujidade ensebada de óleos e graxas não é menos do que sórdido. Esses homens vivem, assim, em sórdidos mundéus. Em seus excessos, bebem Grog, "grogue”; no Aulete atual: "bebida alcoólica, com açúcar e limão, misturada com água quente”. No Aulete original: "bebida feita com rum ou aguardente, água, açúcar e casca de limão”. Na obra de Jahnn aparece como bebida comum das regiões portuárias. Nessas regiões, Grog, "grogue”, é uma bebida muito apreciada pelos marinheiros e estivadores: chá preto com rum; aquece, alegra e embebeda.

No conto, o capitão não quer se comportar como os membros da tripulação. Ele se diz ser "esse outro que atingiu a meta, que está satisfeito, querendo ficar aqui para sempre, sem malbaratar a vida com porres, com prostitutas ou com responsabilidades de pai e de esposo [...]”. Em alemão verschlechtern significa também "agravar”, "piorar”, “deixar a vida pior do que já é”; aqui nos dá a ideia de "desperdiçar”, “dilapidar”, “malbaratar”. Mais: “A senhora Larsson até mesmo recusava saber como ele se arranjava com as mulheres” - sabemos pelo narrador que para ele, para Mov, garotas não tinham lá tanta importância. Em alemão, o verbo é halten, no Präteritum, wie er es mit den Mädchen hielt. Em certa acepção, que privilegio, "sair-se bem em situações delicadas ou adversas”, "dar um jeito”, "se arranjar”. Mov o sabia. "[...] O ajuste de conta consigo mesmo tornava-se, de ano a ano, menos exato." Seine Rechenschaft [“conta”, "prestar conta”, “acerto de conta”, "ajuste de conta”] vor sich selbst, parece-nos não só como uma mera referência à passagem que a antecede, em que se fala de

\footnotetext{
${ }^{11}$ Para um melhor acompanhamento desta resposta, recomenda-se, primeiro, a leitura do conto. (N.E.)
} 
“decisões nos negócios”, mas a tudo o que se vinha dizendo de Mov nos parágrafos anteriores acerca de sua existência.

Em um dos momentos de gravidade no conto o sentinela estava saindo quando escutou a pergunta de Mov Faltin: Wo steckt denn das Übel? “Onde está o mal?” Minha escolha por mal fica diagnosticada como no original, Übel, ao contrário do que poder-se-ia esperar em alemão: Wunde: "Onde está o ferimento?” Esse ferimento ou ferida ou chaga ofereceriam uma interpretação mais direta, mas não ocasionariam um certo estranhamento, um vácuo, que, sem dúvida, é proposital. Para tanto: “mal”.

A certo ponto vemos que o capitão cedeu aos desejos do enfermo - seu marinheiro acidentado - com uma prontidão surpreendente, que dormia na cama de Mov Faltin; este, no sofá. "Tratava do enfermo com meigos cuidados [...]". Er pflegte den Kranken mit Sorgfalt. O verbo é pflegen, "cuidar de”, "tratar de”, seguido do substantivo Sorgfalt, “cuidado”, “esmero”. Diante da situação de impotência, em que o capitão se vê responsável pela vida banal de um marinheiro, somado a sua falta de costume em costurar chaga na carne, a despeito disso, Mov lavava-lhe diariamente os pés, as mãos e o rosto, velava atentamente pela ferida, limpava-a e a cobria de curativo. [...] Passava horas em silêncio ao pé do leito do convalescente, atento aos cuidados: em minha leitura, aos meigos cuidados. Na relação entre o capitão e o marinheiro ferido - seu paciente -, ocultase seu significado real.

Com base nesse último caso, passo à leitura da tradução do conto de Jahnn enquanto peça literária única, que diz de sua visão de mundo, que para ele não é apenas a sociedade humana; é o Universo, a Natureza. O homem faz parte dessa Natureza. Ele é, como todos os seres, perpassado pelas forças que a regem. Para ele, o homem não está acima dos animais, apenas se apropriou dessa superioridade explorando as outras criaturas. Sua obra, portanto, apresenta uma inabalável fraternidade para com os humilhados e as vítimas, uma complacência ampla e generosa. Ele se agita de uma fraternidade real, de um encontro com as outras criaturas, e não de uma atitude condescendente.

ST: Após a publicação de tua tradução de A noite de chumbo (2004), publicaste a coletânea de contos 13 nicht geheure Geschichten (Treze histórias singulares) (2011). Em conversa prévia a esta entrevista, nos contaste que possuis a obra completa de Jahnn, composta de doze robustos volumes, mais de treze mil páginas, de romances, contos, roteiro de cinema, peças de teatro e escritos sobre literatura, arte e política, editada pela Hoffmann und Campe. Olhando para o futuro, qual teu próximo projeto de tradução a partir dessa obra?

MT: Meu atual projeto de pesquisa é uma tradução comentada ao português do Brasil de Perrudja, romance de Jahnn, acompanhando-a de notas críticas que permitam ao leitor contemporâneo visualizar sua dimensão literária. Nisso, buscarei situar sua prosa dentro da tradição literária alemã. Pretendo ir a Alemanha em busca de informações, principalmente oriundas da imprensa, a fim de entender as causas geradoras do silêncio em torno do nome desse grande escritor, e ajudar a romper esse silêncio. Meu encontro com a obra de Jahnn gerou em mim o ofício do tradutor, acreditando que essa iniciativa, que constitui uma prática comunicativa como manifestação de cultura, do ponto de vista universalista 
e humanista, possa vir a contribuir para o estudo da recepção da obra de Hans Henny Jahnn.

Vagarosamente vamos devolvendo algumas obras ao seu lugar de destaque na prateleira da sala vazia cravada no subterrâneo da Praça da Ópera em Berlim. Dos vinte mil exemplares queimados, cinco deles foram recuperados e traduzidos por mim. O silêncio e o vazio entorno dessas obras faz-nos lembrar as palavras do poeta Chico Buarque quando canta "o copo vazio que está cheio de ar, o mesmo ar vazio de um rosto sombrio que está cheio de dor. E é sempre bom lembrar que o ar do copo ocupa o lugar do vinho e o vinho busca ocupar o lugar da dor e a dor ocupa metade da verdade...” 


\section{MoV}

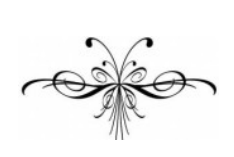

\section{HANS HENNY JAHNN}

\section{Marcus Tulius Franco Morais (TRADUTOR)}

Der älteste Sohn Faltins, Mov, war dem Großvater nachgeschlagen. Er ging auf die See, er besuchte die Schulen und lernte sich an alle Examen heran. Er war fleißig und sehr still. Er wurde, bald nachdem er sein Patent erworben hatte, Kapitän und führte ein kleines Frachtschiff für eine unbedeutende Reederei in Höganaes. Seine Uniform war nicht prächtig: ein abgetragener blauer Jackettanzug mit ankergeschmückten vergoldeten Knöpfen und ein paar zerschlissenen Tressen am Ärmel. Er schlug sich an den kleinen Plätzen, die das Schiff anlief, mit Maklern, Verladern, Schiffshändlern herum. Er hatte harte Tage und Nächte, wenn die See schwer war und mit der Schute spielte, ihr Schläge versetzte, dass sie in allen Spanten erzitterte. Er hörte die Stimmen der Mannschaft: „Kapitän, Kapitän, heute geht es nicht gut, heute nimmt sie uns”. Er saß in seinem kleinen niedrigen Kartenzimmer, zirkelte den Kurs aus, hörte die Worte, das Geheul, das tiefe Stöhnen der Dampfkessel. Die Lampe schaukelte, der alte, drehbare Mahagoniesessel knarrte unter dem schwankenden Gewicht des Mannes. Im Raume roch es nach Medizin, weil eine Flasche in der Arzneikiste ausgelaufen war. - Das war seine Welt. Bis hierher war er gekommen. Da-
O filho mais velho de Faltin, Mov, era parecido com seu avô. Cresceu no mar, frequentou a escola e se preparou para todos os exames. Era dedicado e muito quieto. Logo após ter adquirido a patente de capitão passou a conduzir um pequeno cargueiro de uma modesta companhia de navegação em Höganaes. Seu uniforme não era suntuoso: uma jaqueta surrada azul com botões dourados adornados com âncoras e, nas mangas, um par de galões puídos. Nos lugarejos onde o navio atracava, fazia negócios com corretores, estivadores e negociantes de secos e molhados. Vivia dias e noites difíceis quando o mar estava agitado e brincava com o barco, dando-lhe golpes que o faziam estremecer em todos os cantos. Ouvia as vozes da tripulação: “Capitão, capitão, hoje a coisa não vai bem, hoje o mar vai nos pegar". Ficava na cabina pequena e baixa, cheia de tabelas e de cartas, medindo o curso com o compasso, ouvindo os rogos, o alarido e o grave suspiro da caldeira. A lâmpada balançava, a velha poltrona giratória de mogno rangia sob o peso oscilante do homem. O cômodo cheirava a remédio que havia escorrido de um frasco da caixa de medicamentos. Era esse seu mundo. Havia chegado até aí. Seu sonho de menino. Era um ofício penoso. O armador não estava 
von hatte er geträumt, als er ein Kind war. Und es war ein schwerer Dienst. Der Reeder war nicht mit ihm unzufrieden; aber er tat so, als ob er mit ihm unzufrieden wäre. Immer sollte die Kost für die Mannschaft billiger angeschafft werden, immer die Frachtraten hinaufgesetzt. Aber Mov klagte niemals; wahrscheinlich war er selbst mit diesem Teil seines Loses zufrieden.

Die Matrosen, die Heizer waren weniger als er, hausten in schmierigen Löchern. Ihre Kleidung roch nach Tran oder Heringen. Sie waren geringere Leute als er; aber er liebte sie wie sich selbst. Er hatte keinen Dünkel. Doch er saß an dem Teakholztisch mit den merkwürdig gedrechselten Beinen, mit den Barrieren rings um die Platte, damit Karten, Winkelmesser und Zirkel nicht herabgeschleudert würden. Ein Mann der Wache meldete etwas. Der Kapitän antwortete. Er hatte sein Schiff. Es war nichts Großartiges. Aber er liebte es. Er wollte nicht einmal ein anderes. Er war nicht herrschaftlich genug, um ein großes oder prächtiges zu führen. Er richtete sich mit seinem Leben ein.

Frau Larssons Auskünfte über ihn waren nicht viel ergiebiger. Sie wusste indessen auch, dass er nicht verheiratet war, kaum ein Duzend Freitage im Jahre hatte und sie nicht dazu verwandte, um auf Brautschau zu gehen. Zwar lehnte Frau Larsson es ab, zu wissen, wie er es mit den Mädchen hielt; aber sie war überzeugt, dass sie ihm nichts Erhebliches bedeuteten.

Er war in der Tat sehr anspruchslos, wenig getrieben. Er beneidete seine Leute wegen der Ausschreitungen, die sie begingen. Er beneidete sie und bewunderte sie. Er kam selbst in den Häfen kaum aus insatisfeito com ele, mas se portava como se o estivesse. Era preciso manter baixas as despesas com a tripulação e elevar as parcelas do frete. Mas Mov nunca se queixava; provavelmente estava satisfeito mesmo com esse quinhão do seu destino.

Os marinheiros e os foguistas eram menos do que ele, alojavam-se em sórdidos mundéus. Suas roupas cheiravam a óleo de baleia e a arenque. Era gente menor do que ele, mas ele os amava como a si mesmo. Não havia nele soberba. Ficava sentado à mesa de teca, de curiosas pernas torneadas, com o tampo rodeado por pequenas barreiras para que as cartas náuticas, o astrolábio e o compasso não escorregassem. Um sentinela fazia comunicados. O capitão respondia. Ele tinha seu navio. Não era nada grandioso, mas ele o amava. Nem sequer desejava um outro. Não ostentava grandeza para comandar um navio maior ou mais portentoso. Estava adaptado à sua vida.

As informações que a senhora Larsson dava sobre ele não eram das mais esclarecedoras. No entanto, ela também sabia que ele não era casado, mal chegava a uma dúzia os dias de folga que tirava por ano e nem assim os aproveitava para procurar uma noiva. A senhora Larsson até mesmo recusava saber como ele se arranjava com as mulheres; contudo, não duvidava que, para ele, garotas não tinham lá tanta importância.

Na verdade, Mov era bastante modesto, pouco ambicioso. Invejava sua tripulação pelos excessos perpetrados. Invejava-os e os admirava. Se dependesse dele, nem nos portos deixaria sua cabina, a menos que 
seiner Kajüte heraus, außer, dass er Makler, Verlader, Händler in Geschäften aufsuchte. Zuweilen sagte er ein paar dunkle pessimistische Worte. Man behielt sie, weil sie ganz unvermutet von seinen Lippen kamen. „Wir mühen uns ein paar Jahrzehnte ab, jeder auf seine Weise. Eines Tages legen sie uns in einen Kasten und graben uns ein.” Man antwortete ihm: „So ist es.” Oder auch: „Es hat keinen Zweck, daran zu denken.”

Er dachte auch nicht oft daran. Nur zuweilen, wenn er sich in seiner Koje ausstreckte, das Wetter auf dem Meere still war, oder draußen der abendliche Kai mit seinen elektrischen Lampen durch die Bullaugen hereinschwieg, der Lärm nur noch die Stimme eines betrunkenen Matrosen hatte, der Geruch von Tran, Heringen, faulem Obst und scharfem Käse mit einem lauen Abendwind eindrang - dann dachte er, dass er bald oder ein wenig später verschwinden würde, verschwinden, wie er gekommen. Dann wiederholte er sich: „Bis hierher bin ich gekommen. Das habe ich erreicht. Das war mein Ziel. Dafür bin ich auf die Schulen gegangen. Dafür habe ich alle Ängste der Examen auf mich genommen. Damit ich nicht vergesse, was ich erreicht habe, sind noch alle Knabenängste bei mir. Darum werde ich niemals ein ganzer Mann werden. Damit ich nicht vergesse, dass ich dies erreicht habe, dass ich diese Hütte bewohne, in dieser Koje ausgestreckt liege, dies Schiff führe, diese Mannschaft unter mir habe, die Heizer und die Gasten. - Ob sie mir ansehen, dass ich ein halbwüchsiges Kind geblieben bin? Dass ich niemals auf ähnliche Weise wild bin, wie sie es sind? Dass ich meinen Grog nur trinke, weil andere Kapitäne es tun?”

Er fühlte dann, eine Stunde fosse atrás de corretores, estivadores e mercadores para as negociações. Às vezes dizia algumas palavras pessimistas. Ficavam na memória, pois saíam de sua boca inesperadamente: "Labutamos durante umas décadas, cada um à sua maneira. Um dia nos metem em uma caixa e nos enterram”. Respondiam-lhe: “As coisas são assim”. Ou mesmo: "De nada adianta pensar nisso".

Ele mesmo não pensava muito nisso. Só às vezes, espichado em seu beliche, se estivesse calmo o mar, se pelas vigias entrasse o silêncio vesperal do cais com suas lâmpadas elétricas, se o barulho não fosse mais do que a voz de um marujo embriagado, se o vento tépido da tarde trouxesse o cheiro de óleo de baleia, arenque, fruta podre, queijo ardido então ele pensava que, mais cedo ou mais tarde, desapareceria, desapareceria como chegara. Depois repetia para si: "Cheguei até aqui. Eis o que alcancei. Esse era o meu objetivo. Por isso frequentei as escolas. Por isso suportei todo o medo dos exames. Para não me esquecer do que alcancei, guardei todos os medos da infância. Sendo assim, nunca me tornarei um homem pronto. Para não me esquecer de que cheguei até aqui, de que moro nesta cabina, fico espichado sobre este beliche, comando este navio e tenho sob os meus mandos esta tripulação, os foguistas e os marinheiros. Será que eles percebem que permaneci um adolescente? Que nunca sou bárbaro como eles? Que só bebo meu grogue porque outros capitães o fazem?”

Em seguida, durante uma hora, 
lang, ehe er einschlief, dass er glücklich war, dass er keinen Wunsch hatte, außer: immer hierzubleiben, der zu bleiben, der er war, ein unfertiger Mann, doch ein Kapitän auf einem kleinen Frachtdampfer, beladen mit den Sorgen seines Reeders; - allen Tücken des Meeres und der Menschen an den Hafenplätzen ausgesetzt; aber immer in der Gewissheit, dass sein Schiff seine Zuflucht war. An diesen Platz war er gestellt worden. Er konnte ihn ausfüllen. Er verstand es, das Schiff zu führen, die Geschäfte an den Hafenplätzen befriedigend zu erledigen. Er war auf die rechte Weise schroff und weich gegen die Mannschaft. Er verriet niemals, wer er war, dass die abendlichen Stunden in seiner Koje diese seltsame Mischung aus Glück und Verzagtheit hatten. „Gott hat mir bestimmt, dass ich kein Mädchen heiraten soll. Ich werde keine Kinder haben. Das ist mir bestimmt. Das weiß ich. Meine Schwester Olga wird viele Kinder haben; aber ich werde nie ganz erwachsen sein. Ich werde immer schüchtern bleiben. Vielleicht bereiten mir die Mädchen keine große Freude. Ich schäme mich vor ihnen. Ich schäme mich sogar vor einer Hure. Ich schäme mich nicht vor mir selbst. Gott hat mich so gemacht, wie ich bin, mit dieser Angst im Herzen, dass ich womöglich niemals so erwachsen sein werde wie der Küchenjunge Sophus, der doch erst siebzehn Jahre alt ist - und mit dieser Freude, dieser unablässigen Freude, dass ich alle Examen bestanden habe und Kapitän geworden bin. Ich habe wahrhaftig schon vergessen, dass ich ein Schiffsjunge war, ein Matrose, ein geringer Mann auf unbekannten Schiffen. Ich bin jetzt der andere, der am Ziel ist, der zufrieden ist, der hier bleiben will, der immer hier bleiben will, der sein antes que adormecesse, sentia que era feliz, que não tinha sequer desejo, salvo o de permanecer sempre ali, continuar sendo quem era, um homem inacabado, porém um capitão em um pequeno cargueiro carregado das inquietações de seu armador, exposto a todas as traições do mar e dos homens nos portos, mas sempre com a certeza de que seu navio era seu refúgio. Deram-lhe esse posto. Ele podia preenchê-lo. Sabia comandar o navio e realizar de modo satisfatório os negócios portuários. Ele era, na medida certa, intratável e dócil com a tripulação. Jamais revelava quem era, que as horas vesperais em sua cabina tinham uma estranha mistura de gozo e desalento. "Deus determinou não me casar. Não terei filhos. Esse é o meu destino. Eu sei. Minha irmã Olga terá muitos filhos; mas eu nunca serei inteiramente adulto. Permanecerei sempre tímido. Talvez as mulheres não me proporcionem muito prazer. Sinto-me envergonhado diante delas. Sinto-me envergonhado até mesmo diante de uma prostituta. Não me envergonho diante de mim mesmo. Deus me fez assim como sou, com o coração cheio desse medo de nunca ser tão adulto quanto Sophus, o ajudante de cozinha, com seus dezessete anos, e com esse contentamento, esse constante contentamento por ter sido aprovado em todos os exames e por ter-me tornado capitão. Eu realmente já ia me esquecendo que fui grumete, marinheiro, um homem insignificante em navios desconhecidos. Agora sou esse outro que atingiu a meta, que está satisfeito, querendo ficar aqui, ficar aqui para sempre, sem malbaratar a vida com porres, com prostitutas ou com responsabilidades de pai e de esposo, querendo permanecer adolescente, para sempre, e, no mais, capitão.” 
Leben weder durch Trunk oder Huren verschlechtern will, durch keine Verantwortung für Frau und Kinder - der immer ein Halbwüchsiger bleiben will und ein Kapitän dazu - - -”

Er grübelte nicht über sich, er machte nur Feststellungen, Feststellungen ohne Reue, ohne Ver-langen, dass es anders sein möchte. Er wusste kaum, was eine Gewissensprüfung ist. Er bedurfte ihrer nicht. Er musste nur von Zeit zu Zeit den Platz erforschen, an dem er stand. Er sagte nicht einmal mit ganzer Deutlichkeit: „Das bin ich; so bin ich.” Allenfalls räumte er ein: „Möglicherweise steht es so mit mir." Er sagte auch: „Ich schulde niemand etwas. Ich habe niemand im Stich gelassen. Ich verlasse mich auf niemand. Zwar - ich bin mir selbst nicht genug. Ich habe meine Ängste. Ich bin mir zuweilen abtrünnig. Aber ich habe mein Schiff, meine Mannschaft, meine Beschäftigung und die unvergleichbare Einsamkeit meiner Kajüte. Freilich, eines Tages wird man mich in einen Kasten legen und eingraben. Dann ist dies alles gewesen - und ich weiß nicht einmal mehr wozu. Dies ist, damit auch ich esse und lebe, ernährt werde und mich nützlich mache. Jeder Mensch hat seinen Beruf, und ich habe diesen.”

Die Züge seines Antlitzes waren die eines Mannes, der das Meer befährt. Seine grauen Augen blickten scharf. Seine Hände waren sicher; sie zitterten niemals. Er konnte ein halbes Duzend Gläser starken Punsch trinken, ohne dass ihm jemand etwas angemerkt hätte. Seine Entscheidungen in Geschäften waren klar. Seine Rechenschaft vor sich selbst wurde von Jahr zu Jahr ungenauer. Es unterliefen immer mehr Ereignisse, die nicht oder nur oberflächlich geprüft wurden. So kam auch jede Nacht, die er nie vergaß,
Não refletia sobre si mesmo, fazia apenas constatações, constatações sem arrependimentos, sem desejar que tudo pudesse ter sido diferente. Nem mesmo sabia o que era um exame de consciência. Não precisava disso. Ele precisava apenas, de tempos em tempos, examinar o lugar por onde andava. Nem sequer dizia com toda clareza: "Eis o que sou; eis como sou”. Quando muito concedia: "É isso, talvez, o que acontece comigo". Dizia também: "Não devo nada a ninguém. Não abandonei ninguém. Não me fio em ninguém. Na verdade, não me basto. Tenho meus temores. Renego, às vezes, a mim mesmo. No entanto, tenho meu navio, minha tripulação, minha ocupação e a incomparável solidão da minha cabina. Sem dúvida um dia vão me pôr em uma caixa e me enterrar. Depois tudo terá se cumprido - e eu nem sequer sei para quê. As coisas são assim, para que eu também coma e viva, seja nutrido e me faça útil. Cada homem tem seu ofício, e esse é o meu”.

Os traços de seu rosto eram os de um homem que navega por mares. Seus olhos cinzentos miravam penetrantes. Suas mãos eram firmes, nunca tremiam. Podia beber meia dúzia de copos de ponche forte sem que alguém notasse. Suas decisões nos negócios eram claras. O ajuste de conta consigo mesmo tornava-se, de ano a ano, menos exato. Sobrevinham cada vez mais incidentes que eram ignorados ou examinados apenas superficialmente. Assim foi aquela noite que ele nunca esqueceu, embora sua consciência não quisesse 
für die sein Gewissen nicht einstehen wollte, jene Nacht, in der James Botters verunglückte. Sie wurden auf hoher See von schwerem Wetter überrascht. Der Ozean kam über die Reling. Das Deck war glatt. Botters ging in der Finsternis von vorn nach achtern. Ganz unerwartet, gegen die Regel des pendelnden Schlingerns, entwich der Boden unter seinen Füßen. Er glitt aus, fiel, rollte wie ein Stück Holz gegen die Schiffswand. In jenem Augenblick schrie er. Schrie so laut, dass es den Sturm durchschnitt. Sogleich gischtete das Wasser über ihn hinweg, zischte. Er konnte nicht hoffen, dass jemand ihn gehört hatte. Er erhob sich, klammerte sich an, spürte ein unbeschreiblich eisiges Gefühl an seinem Leibe.

Da stand der Kapitän vor ihm, zum wenigsten war es seine Stimme. „Was ist mit dir, Botters?” „Ich glaube, hier ist ein Haken - - -”, sagte der Matrose, machte eine Handbewegung, die der andere in der Finsternis nicht erkennen konnte. „Was für ein Haken?” fragte der Kapitän. „Ich glaube, wir müssen einmal nachsehen -" Unaufgefordert legte der Matrose seinen Arm um den Hals des Kapitäns und begann $\mathrm{zu}$ schluchzen. „Bist du gefallen? Bist du verwundet?” „Ich bin gefallen. Ich glaube, ich bin verwundet.” Die Zähne des Mannes schlugen aufeinander. Der Kapitän Mov Faltin stütze den Matrosen, half ihm die Treppe zum oberen Deck hinauf. Dort begegnete ihnen ein Mann der Wache. James Botters berührte ihn mit seiner freien Hand. Als der Mann stehen blieb, schlang Botters den zweiten Arm um dessen Hals. Er ließ sich mehr tragen, als dass er ging. In der Kajüte des Kapitäns blieb er allein aufrecht stehen. Er fiel nicht, obgleich der Boden unter admitir; aquela noite em que James Botters sofreu um acidente. Foram surpreendidos em alto mar por uma tempestade. O oceano ultrapassara a balaustrada. O convés estava escorregadio. Botters andava nas trevas da proa à popa. Inesperadamente, contra o ritmo do balanço, o solo fugiu-lhe dos pés. Escorregou, caiu, rolou como um pedaço de madeira contra a parede do navio. Então deu um grito tão forte que o grito atravessou a tormenta. No mesmo instante, a água espumando cobriu-lhe o corpo, esfuziando. Ele não imaginava que alguém o tivesse ouvido. Levantou-se, apoiando-se; uma sensação de frio indescritível percorreulhe o corpo.

De repente, o capitão estava em pé diante dele, pelo menos era a sua voz. "O que há com você, Botters?" "Acho que tem um gancho aqui”, disse o marinheiro, fazendo um gesto com a mão, que o outro não pôde distinguir na escuridão. “Que estória é essa de gancho?”, perguntou o capitão. "Acho que é preciso verificar.” E, sem mais, o marinheiro abraçou o pescoço do capitão e começou a soluçar. "Você caiu? Você está ferido?” “Caí. Acho que estou ferido.” O homem estralejava com os dentes. O capitão Mov Faltin amparou o marinheiro, ajudando-o a subir para o tombadilho. Lá em cima encontraram com o sentinela. James Botters o tocou com sua mão livre. Quando o homem parou, Botters envolveu-lhe o pescoço com o segundo braço. Assim amparado, deixou-se levar. Na cabina do capitão pôs-se de pé. Não caiu, embora o chão dançasse. O sentinela estava saindo quando escutou a pergunta de Mov Faltin: "Onde está o mal?” James Botters mostrou o ven- 
seinen Füßen tanzte. Der Mann der Wache wollte sich schon entfernen. Doch er hörte Mov Faltins Frage: „Wo steckt denn das Übel?” Und James Botters wies auf seinen Bauch. Der Kapitän entzündete eine kleine messingene Handlampe und leuchtete auf die Stelle. Da sahen sie, dass die Hose am Bund zerrissen war, und aus dem Riss schaute etwas hervor, vergleichbar einer Blase, graurosa von Farbe. Aber es war nicht Haut, nicht Fleisch, nicht Blut. Und es war groß wie eine Walnuss. „Wir müssen ihn aufs Bett legen”, sagte der Kapitän. James Botters schritt aus eigenem Antrieb schwankend zum Bett, und der Mann, der Wache hatte, half ihm, sich hinzustrecken. Er zog ihm auch die Stiefel von den Füßen. Er streifte ihm die Bluse über den Kopf. Dann hörte er wieder die Stimme Mov Faltins, einen Befehl: „Geh jetzt! Sage niemand, was du gesehen hast! Ich werde allein damit fertig werden.” Er drängte den Mann hinaus, verriegelte die Tür. Er schraubte den Docht der Lampe so hoch wie es anging, ohne dass sie rußte. Er zog die Medizinkiste hervor. Dann erst wandte er sich dem Verunglückten wieder zu. Er entkleidete ihn ganz. Und so sah er denn den Matrosen James Botters, sechsundzwanzig Jahre alt, klein an Wuchs, mit verkrüppelten schmutzigen Zehen, breitem Becken, so dass der Gang des Menschen x-beinig war, weißhäutig, unbehaart, grobhändig, durch keine Schönheit ausgezeichnet, ein durchschnittlicher Mensch, wie er von den Müttern kommt. Aber aus seinem Leibe war, groß wie eine Walnuss, durch eine Wunde, die kaum noch blutete, die braun umrandet war, eine Schlinge des Darms hervorgetreten. Dem Matrosen schlugen die Zähne in Kälteschauern wieder aufeinander. Mov Faltin gab ihm ein tre. O capitão acendeu uma lanterna pequena de latão e iluminou o local indicado. Então viram que a calça estava rasgada no cós e do rasgão saía qualquer coisa comparável a uma bolha de cor rosa-cinza. Mas não era pele, nem carne, nem sangue. Tinha o tamanho de uma noz. "Temos que colocá-lo na cama”, disse o capitão. Cambaleando James Botters caminhou por vontade própria e o sentinela o ajudou a se deitar. Ainda descalçou-lhe as botas. Tirou-lhe a camisa por sobre a cabeça. Então ouviu novamente a voz de Mov Faltin, uma ordem: “Agora vá! Não diga a ninguém o que viu! Darei um jeito em tudo sozinho". Pôs o homem para fora e trancou a porta. Torceu a mecha do candeeiro tão alto quanto pôde sem soltar fuligem. Pegou a caixa de medicamentos. Só então se ocupou do acidentado. Despiu-o completamente. Assim pôde ver o marinheiro James Botters, de vinte e seis anos de idade, de estatura pequena, com os dedos dos pés imundos e estropiados, ancas largas que lhe davam um trejeito cambaio, pele branca, glabra, mãos grossas, não distinguido por qualquer beleza, um homem comum, tal como saem do ventre materno. Mas do seu corpo, por um ferimento tarjado de castanho que ainda sangrava um pouco, saía um nó do intestino grande como uma noz. Com calafrios, o marinheiro voltou a bater os dentes. Mov Faltin deu-lhe uma dose de conhaque. "Preciso suturá-lo", disse Mov para si, "preciso resolver isso, senão ele estará morto em dois dias.” Foi buscar algodão e clorofórmio. Fez o marinheiro inalar a emanação adocicada do anestésico. Esperou alguns minutos, leu as instruções de como suturar chaga na carne. Quando iniciou a obra, não sabia se o acidentado dormia profundamente, se estava desmaiado ou acordado. Mas não era 
Viertelwasserglas voll Kognak. „Ich werde ihn zunähen müssen”, sagte Mov Faltin zu sich selbst, "ich werde dies Schwierige ausführen müssen, denn er wird sonst in zwei Tagen tot sein.” Er suchte Watte und Chloroform hervor. Er ließ den Matrosen den süßlichen Dampf des Betäubungsmittels einatmen. Er wartete ein paar Minuten, las die Beschreibung, wie man Fleischwunde vernähe. Er wusste nicht, wie tief der Schlaf des Verunglückten war, ob er bewusstlos war oder noch wachte, als er sich ans Werk machte. Aber darauf kam es auch nicht an. Der Kapitän betupfte die schwammige Blase, die aus dem Bauche hervorgetreten war, mit einer desinfizierenden Flüssig-keit. Er tauchte die eigenen Finger in die gleiche Flüssigkeit. Mit einem dieser Finger stieß er den Darm durch die Öffnung im Leibe zurück.

Dann vernähte er sie kunstlos, doch emsig, mit einer Anzahl Stichen. Er trieb die krumme Nadel durch Haut und Fleisch. Er tropfte noch einmal mit Bedacht Chloroform auf den Wattebausch, der das Gesicht des Matrosen bedeckte. Dann betrachtete er sein Werk. Nein, er betrachtete das Werk des Schöpfers, den Menschen, der verunglückt war, der leben oder sterben würde. Und dies Anschauen bereitete ihm ein so unermessliches Glück, einen Genuss von so unirdischer Größe, dass er sich nicht losreißen konnte. Ja, er tröpfelte, gegen alle Vernunft, nochmals vom öligen Chloroform auf das Gesicht des Matrosen. Endlich kniete er neben dem Bette nieder und begann zu beten. Er betete zu Gott, dass dieser Mensch genesen möge, dass die schwache, unfachmännische Hilfe ausreichen möge, dies durchschnittliche Leben eines Matrosen zu erhalten. Er, der das isso o que importava. O capitão passou um líquido desinfetante na bolha esponjosa que saía do ventre. Mergulhou os dedos no mesmo líquido e com o dedo empurrou o intestino de volta pelo orifício no corpo.

Depois suturou-o com uns tantos pontos; sem arte, mas com desvelo. Forçou a agulha curva pela pele e carne. Com cautela, pingou outra vez clorofórmio sobre o chumaço de algodão que cobria o rosto do marinheiro. Então, contemplou sua obra. Não, ele contemplou a obra do Criador, o homem acidentado que ia viver ou morrer. E essa contemplação lhe proporcionou uma felicidade incomensurável, um gozo de magnitude sobrenatural, do qual foi incapaz de se desvencilhar. Sim, contra todo o juízo e a razão, voltou a pingar clorofórmio oleoso sobre o rosto do marinheiro. Por fim, ajoelhou-se ao lado da cama e começou a rezar. Pediu a Deus para que esse homem se curasse, para que sua parca ajuda inábil valesse para salvar a vida banal de um marinheiro. Ele, que não sabia rezar, que não tinha esse hábito, ficou ajoelhado meia hora diante do leito, sussurrando fragmentos de 
Beten nicht verstand, keine Übung darin hatte, lag eine halbe Stunde vor dem Bette auf den Knien und lispelte unvollendete Gedanken und Beschwörungen, bemühte Jenen, den er nicht kannte, wollte ihn zwingen, sich in dies Ereignis einzumischen. So fleht ein Knabe um die Genesung eines Kameraden. Mit tränenerstickter Stimme, mit weltengroßer Angst im Herzen, mit Jubel über ein Gefühl im Fleisch, das neu ist.

Endlich erhob er sich, halb betäubt von seinem Gestammel, vom Stampfen und Schlingern des Schiffes, vom Chloroformgeruch. Er wusch die Wunde, die wie ein verklebter Mund war, mit Äther, brachte ein Pflaster darüber an, packte den Kranken fest in die Decken ein, nahm ihm den Wattebausch vom Antlitz. Dann riegelte er die Tür auf, schritt in die Nacht hinaus, tastete sich zur Brücke. Wie er über die Brüstung hinausstarrte, auf das Vorschiff, gegen das die schwarzen Wellen mit grau schimmernden Kämmen anritten, erkannte er, was mit ihm geschehen war. Er sah noch einmal das Bild James Botters, dort unten auf dem Grunde der Schwärze, die kleine weiße Gestalt, aus der ein wenig Darm hervorgetreten war. Willenlos betäubt oder halb betäubt, in die Gewalt Faltins gegeben. Und er wusste eine Minute lang, er hatte jenen betrachtet, als ob er ihn liebe. - Er vergaß diese Nacht niemals, aber er verheimlichte ihren eigentlichen Inhalt sehr bald vor sich selbst. Botters genas. Die Wunde eiterte ein paar Wochen lang; dann schloss sie sich, ohne einen Schaden im Bauch zu hinterlassen. Als man nach zwei Tagen einen Hafen anlief, drang der Kapitän darauf, dass Botters in ein Krankenhaus komme. Aber der weigerte sich. Er lag noch immer im Bett des Kapitäns, wurde pensamentos e exortações, suplicando a Ele, que ele não conhecia, querendo forçá- $L o$ a intervir no curso das coisas. Assim roga um menino pelo restabelecimento de um companheiro, com a voz embargada pelas lágrimas, com um temor do tamanho da Terra em seu coração, com regozijo proporcionado por uma sensação nova na carne.

Por fim se levantou, semiaturdido pela sua algaravia, pelos trancos e solavancos do navio, pelo cheiro do clorofórmio. Lavou com éter a ferida que se assemelhava a uma boca colada, cobriu-a com curativo, envolveu o enfermo em cobertores e retirou-lhe o chumaço de algodão do rosto. Depois abriu a porta, saiu para a noite, tateando rumo à ponte. Parou junto à balaustrada com o olho pregado na proa, onde as ondas pretas montavam com cristas de um cinza cintilante, e inteirou-se do que lhe havia ocorrido. Viu mais uma vez a imagem de James Botters, a pequena forma branca no meio da escuridão, da qual uma ponta do intestino havia saído, anestesiado ou inconsciente, entregue ao domínio de Faltin. E durante um minuto soube que havia contemplado esse homem como se o amasse. Nunca se esqueceu dessa noite, mas logo ocultou de si mesmo seu significado real. Botters se restabeleceu. Durante algumas semanas a ferida permaneceu purulenta; depois cicatrizou, sem deixar dano no ventre. Ao chegarem a um porto, o capitão insistiu para que Botters fosse levado a um hospital. Mas ele recusou-se a sair. Ainda permaneceu deitado na cama do capitão, alimentado com sopa leve de aveia. Não quis deixar o barco. O capitão cedeu aos desejos do enfermo com uma prontidão surpreenden- 
mit dünner Hafersuppe ernährt. Er wollte nicht von Bord. Der Kapitän gab dem Wunsche des Kranken merkwürdig schnell nach. Botters blieb in seinem Bette, Mov Faltin schlief noch drei Wochen lang auf einem Sofa. Er pflegte den Kranken mit Sorgfalt, wusch ihm täglich Füße, Hände und Antlitz, überwachte ängstlich die Wunde, reinigte sie, bepflasterte sie. Er befahl eine äußerst karge Diät, beschaute den Darmabgang. Stundenlang saß er schweigend neben dem Lager des Genesenden, dessen Hände allmählich so weiß wurden wie der übrige Körper. Dann wurde die alte Ordung wieder hergestellt. James Botters zog ins Logis der Matrosen.

„Ich habe nur meine Pflicht getan”, sagte Mov Faltin am Ende der für ihn so erregenden Wochen zu sich selbst. Später öffnete er zuweilen den Stöpsel der Chloroformflasche, atmete einen süßlichen Ruchschwaden ein, beschwor einen Traum herauf, dem er keinen Namen gab. „Ich werde immer hier bleiben. Ich kann nirgendwo so gut schlafen wie in meiner Koje. Ich habe keine andere Heimat. Mich verlangt nicht nach den Häfen.” Er bereitete niemand Kummer, nicht einmal Überraschungen. te. Botters permaneceu na cama, Mov Faltin dormiu ainda por três semanas no sofá. Tratava do enfermo com meigos cuidados, lavava-lhe diariamente os pés, as mãos e o rosto, velava atentamente a ferida, limpava-a e a cobria de curativo. Prescreveu uma dieta extremamente frugal, controlava a evacuação. Passava horas em silêncio ao pé do leito do convalescente, cujas mãos tornavam-se pouco a pouco tão brancas como o resto do corpo. Depois a ordem antiga foi restabelecida. James Botters reintegrou-se ao posto dos marinheiros.

"Eu fiz apenas o meu dever", disse Mov Faltin para si mesmo ao cabo dessas semanas tão agitadas. Mais tarde, retirava de vez em quando a rolha do frasco de clorofórmio, inalava da emanação adocicada e evocava um sonho a que não dava nome. "Ficarei para sempre aqui. Em lugar nenhum posso dormir tão bem como na minha cabina. Não tenho outra pátria. Os portos não mais me atraem." Ele nunca causou aflição a ninguém, nem mesmo surpresas. 
Marcus Tulius Franco Morais ugrino2000@bol.com.br Doutorando, Universidade Federal de Santa Catarina

\author{
Gustavo Althoff \\ gualthoff@gmail.com \\ Pós-Doutorando, Universidade Federal de Santa Catarina \\ Cássia Sigle \\ siglecassia@hotmail.com \\ Mestranda, Universidade Federal de Santa Catarina
}

\title{
Referências bibliográficas
}

ANDRADE, Carlos Drummond de. A rosa do povo. 1a. ed. São Paulo: Companhia das Letras, 2012, p.11-12.

BERMAN, Antoine. A Tradução e a Letra ou o Albergue do Longínquo. Tradução de Marie-Hélène C. Torres, Mauri Furlan e Andreia Guerini. 2. ed. Tubarão: Copiart; Florianópolis: PGET/UFSC, 2013.

BERMAN, Antoine. A prova do estrangeiro: cultura e tradição na Alemanha romântica. Bauru: Edusc, 2002.

JAHNN, Hans Henny. A noite de chumbo. Tradução de Marcus Tulius Franco Morais. São João del-Rei: Editora Ugrino, 2004 [1956]. Título original: Die Nacht aus Blei. (Novela).

JAHNN, Hans Henny. O relojoeiro. Tradução de Marcus Tulius Franco Morais. Baleia na Rede, Revista online do Grupo de Pesquisa e Estudos em Cinema e Literatura, São Paulo, UNESP - Universidade Estadual Paulista “Júlio de Mesquita Filho”, Câmpus de Marília, v. 1, n. 5, 2008 [1954]. Título original: Der Uhrenmacher. (Conto). Disponível em: $<$ http://www.marilia.unesp.br/Home/RevistasEletronicas/BaleianaRede/E dicao05/1-traducao.pdf > . Acesso em: 01 junho 2013.

JAHNN, Hans Henny. Fluss ohne Ufer. Frankfurt a.M.: Suhrkamp. 2000.

JAHNN, Hans Henny. Treze histórias singulares. Tradução de Marcus Tulius Franco Morais. São João del-Rei: Editora Ugrino, 2011 [1954]. Título original: 13 nicht geheure Geschichten. (Contos).

JAHNN, Hans Henny. Jeden ereilt es. 1a. ed. Frankfurt am Main: HeinrichHeine, 1968.

JOYCE, James. Ulysses. Tradução de Georg Goyert. Basel: Rhein-Verlag, 1927. 
KAFKA, Franz. Beim Bau der chinesischen Mauer: Ungedruckte Erzählungen und Prosa aus dem Nachlass. Editado por Max Brod e Hans Joachim Schoeps. Berlin: Gustav Kiepenheuer Verlag, 1931.

LUTHER, Martin. Die Bibel. Stuttgart: Deutsche Bibelgesellschaft, 1912.

MORAIS, Marcus Tulius Franco. Lírica no Limbo - Poemas de Selma Meerbaum-Eisinger. Revista 18, São Paulo, ano IV, nr. 17, p. 50 - 53, 01 set. 2006.

MORAIS, Marcus Tulius Franco. Gertrud Kolmar: encanto, recolhimento e obliteração. Revista 18, São Paulo, ano IV, nr. 19, p. 52 - 54, 01 fev. 2007.

MORAIS, Marcus Tulius Franco. O Fascínio da Filicida: Tradução Anotada e Comentada de Medeia, Drama de Hans Henny Jahnn. Dissertação deMestrado do Programa de Pós- Graduação em Estudos da Tradução, Universidade Federal de Santa Catarina, Florianópolis, 2013.

PYM, Anthony. Exploring Tanslation Theories, 1a. ed., London and New York: Routledge, 2009.

ROTH, Joseph. A lenda do santo beberrão. Tradução de Marcus Tulius Franco Morais. São João del-Rei: Editora Ugrino, 2000 [1939]. Título original: Die Legende vom heiligen Trinker. (Novela).

ROTH, Joseph. Rechts und Links. Berlin: Gustav Kiepenheuer, 1929.

VENUTI, Lawrence. The Translator's Invisibility. A History of Translation. London and New York: Routledge, 1995.

WALL, Renate. Verbrannt, verboten, vergessen. Kleines Lexikon deutschsprachiger Schriftstellerinnen 1933 bis 1945. Köln: PahlRugenstein, 1988.

WEDEKIND, Frank. Mine-Haha ou Sobre a educação corporal das meninas. Tradução de Marcus Tulius Franco Morais. São Paulo: Luzes no Asfalto, 2010. Título original: Mine-Haha oder Über die körperliche Erziehung der jungen Mädchen.

WEDEKIND, Frank. O despertar da primavera. Tradução de Claudia Abeling. Luzes no Asfalto, São Paulo, 2010

\section{Outras traduções publicadas}

BEETHOVEN, Ludwig van. Cartas de Ludwig van Beethoven à Condessa Giulietta Guicciard. Tradução de Marcus Tulius Franco Morais. In: TIN, Emerson. Para sempre: 50 cartas de amor de todos os tempos. São Paulo: Globo, 2009. p. 49-54.

KAFKA, Franz. Cartas de Kafka a sua noiva Felice Bauer. Tradução de Marcus Tulius Franco Morais. In TIN, Emerson. Para sempre: 50 cartas de amor de todos os tempos. São Paulo: Globo, 2009. p. 113-124.

MORAIS, Marcus Tulius Franco; FREESE, Nestor Alberto. "Crítica de Tradução”, de Klaus Kaindl. Revista In-Traduções - Revista do Programa de Pós-Graduação em Estudos da Tradução da UFSC, Florianópolis, v. 4, n. 6, p. 180-189, jan./jun., 2012.

\section{Outros textos publicados}


MORAIS, Marcus Tulius Franco. Resgatando o silêncio das entrelinhas: Entendendo o dito que não foi dito. Baleia na Rede, Revista online do Grupo de Pesquisa e Estudos em Arte e Sociedade, São Paulo: UNESP Universidade Estadual Paulista “Júlio de Mesquita Filho”, Câmpus de Marília, v. 9, n. 1, p. 236-247, 2012. Disponível em:

$<$ http://www2.marilia.unesp.br/revistas/index.php/baleianarede/article/vi ewFile/2847/2224>. Acesso em: 01 junho 2013.

MORAIS, Marcus Tulius Franco. Da linguagem polifônica à questão religiosa a cripta do prosador, dramaturgo, editor, arquiteto, organista e organeiro Hans Henny Jahnn. Baleia na Rede, Revista online do Grupo de Pesquisa e Estudos em Cinema e Literatura, São Paulo, UNESP - Universidade Estadual Paulista "Júlio de Mesquita Filho", Câmpus de Marília, v. 1, n. 5, p. 253-258, nov. 2008. Disponível em:

$<$ http://www2.marilia.unesp.br/revistas/index.php/baleianarede/article/vi ewFile/1428/1253>. Acesso em: 01 junho 2013.

MORAIS, Marcus Tulius Franco; CARVALHO, Julia Maria Gomes. Cultura judaica: das terras de Israel às ruas do Bom Retiro. Baleia na Rede, Revista online do Grupo de Pesquisa e Estudos em Cinema e Literatura, São Paulo, UNESP - Universidade Estadual Paulista "Júlio de Mesquita Filho”, Câmpus de Marília, v. 1, n. 4, p. 15-19, 2007. Disponível em:<http://www2.marilia.unesp.br/revistas/index.php/baleianarede/articl e/viewFile/1387/1212>. Acesso em: 01 junho 2013. 


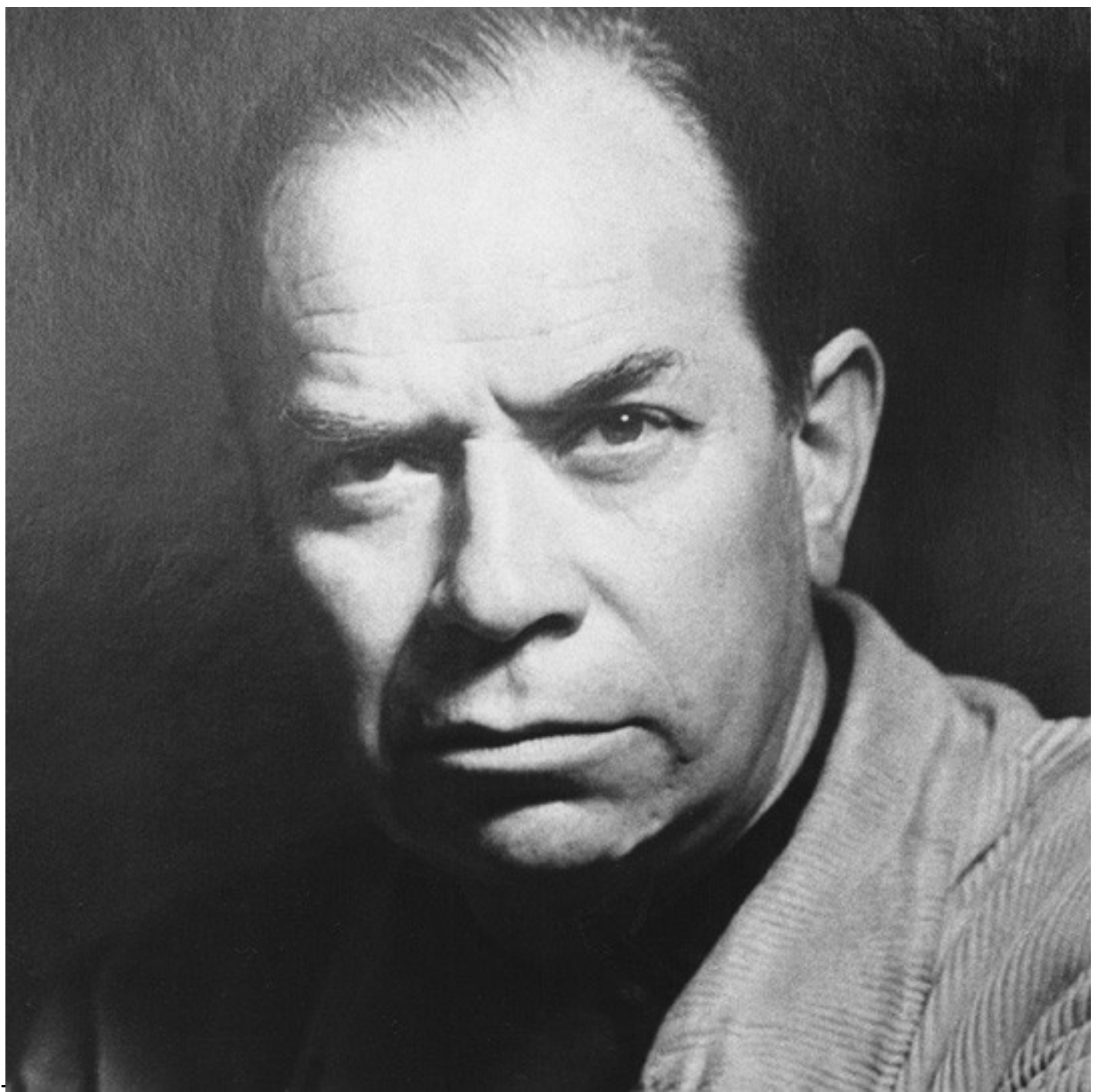

Hans Henny Jahnn (1894-1959), Schöpfer gewaltiger Werke; preto e branca; 540×540 pixels; 91,9Kb Disponível em:

$<$ http://images.zeit.de/kultur/literatur/2009-11/hans-henny-jahnn/hans-henny-jahnn540x540.jpg>.

Acesso em: 12 jul. 2013. 